\title{
A MORTE ANUNCIADA DO \\ PLANO DE DESENVOLVIMENTO FLORESTAL SUSTENTÁVEL DO ESTADO DE SÃO PAULO
}

\author{
Roberto Bretzel Martins \\ Engenheiro Agrônomo
}

Orientador: Prof. Dr. ORIOWALDO QUEDA

Dissertação apresentada à Escola Superior de Agricultura "Luiz de Queiroz", Universidade de São Paulo, para obtenção de título de Mestre em Ciências - Área de concentração: Ciências Florestais.

PIRACICABA

Estado de São Paulo - Brasil

Fevereiro de 2000 


\section{ERRATA E CORRIGENTA}

\begin{tabular}{|c|c|c|c|c|}
\hline p. & item & linha & onde se lê & leia-se \\
\hline viii & & primeira & A conclusão final é que ... & A conclusão é que ... \\
\hline 3 & 1 & segunda & ... decrescendo para $5,3 \%$ vinte anos ... & ... decrescendo para $7,4 \%$ vinte anos $\ldots$ \\
\hline 4 & 1 & terceira & Tal iniciativa ocorreu ... & Uma das iniciativas ocorreu ... \\
\hline 6 & 2 & quarta & ... diversos tipos de atividade. & ... diversos tipos de atividades. \\
\hline 35 & 3.2 & vigésima quarta & $\ldots$ de $15 / 10 / 69)$, prescrevem... & $\ldots$ de $15 / 10 / 69$ ) (sic), prescrevem... \\
\hline 37 & 3.2 & décima quinta & $\begin{array}{l}\text {... em áreas de pequenos e médios } \\
\text { agricultores ... }\end{array}$ & ... em áreas de agricultores ... \\
\hline 48 & 4.2 .2 & décima & $\ldots$ de $15 / 10 / 69)$, prescrevem... & $\ldots$ de 15/10/69) (sic), prescrevem... \\
\hline 62 & 4.2.4.3.3 & vigésima primeira & ... é o Programa de Reposição ... & ... é o mecanismo de Reposição ... \\
\hline 62 & 4.2.4.3.3 & vigésima segunda & Este programa, que objetiva ... & Este mecanismo, que objetiva ... \\
\hline 73 & 4.2.4.3.4 & segunda & ... refere-se à obrigatoriedade legal de ... & ... refere-se à manutenção legal de ... \\
\hline 73 & NR 37 & segunda & ... acordo com o tamanho do imóvel, $\ldots$ & $\begin{array}{l}\text {... acordo com a região e o tamanho do } \\
\text { imóvel ... }\end{array}$ \\
\hline 80 & 4.3 & décima quarta & ... do PDFS Ter-se realizado ... & ... do PDFS ter-se realizado ... \\
\hline 92 & 5 & décima quarta & ... pelos implemetadores do Plano, ... & ... pelos implementadores do Plano, ... \\
\hline
\end{tabular}




\title{
Dados Internacionais de Catalogação na Publicação (CIP) DIVISÃo DE BIBLIOTECA E DOCUMENTAÇÃO - Campus "Luiz de Queiroz"/USP
}

\author{
Martins, Roberto Bretzel \\ A morte anunciada do Plano de Desenvolvimento Florestal Sustentável do Estado \\ de São Paulo / Robero Bretzel Martins. - - Piracicaba, 2000. \\ $101 \mathrm{p}$. \\ Dissertação (mestrado) -. Escola Superior de Agricultura Luiz de Queiroz, 2000. \\ Bibliografia.
}

1. Desenvolvimento florestal 2. Ecologia florestal 3. Economia florestal 4. Planejamento florestal 5. Política florestal 6. Silvicultura sustentável I. Título

CDD 634.92

"Permitida a cópia total ou parcial deste documento, desde que citada a fonte - $O$ autor" 


\section{DEDICATÓRIA}

Aos meus pais

À Geshe Kelsang Gyatso 


\section{AGRADECIMENTOS}

Muito devo ao Professor Oriowaldo Queda, que desde a época da graduação foi solicito e presente na minha formação profissional, com suas sugestões e críticas. Sou muito grato pela sua dedicada e zelosa orientação, paciência e confiança, durante toda a realização deste trabalho.

Também gostaria de prestar agradecimentos ao professor Marcos Sorrentino. Sua provocação, estímulo e sugestões sensibilizaram-me para os problemas ambientais, o que norteou minha vida acadêmica e profissional.

Não poderia esquecer de agradecer a Tânia, pelo apoio, sempre que precisei, ao longo deste trabalho. Sem me ajudar nos momentos mais difíceis, não conseguiria ter a confiança e o amparo necessários para concluir esta dissertação.

À diretoria do ECOAR que, sensibilizada com o meu desejo de ingressar em um curso de pós-graduação, proporcionou-me a oportunidade necessária para realizar esta dissertação, sem que eu precisasse desligar-me da instituição.

Ao João Carlos, meu colega de trabalho, que durante o período desta dissertação sempre me resguardou em minhas atribuições quando necessário. Muito Obrigado.

Ao CNPQ pela bolsa de mestrado durante ano e meio.

A todos aqueles que direta ou indiretamente contribuíram para a realização deste trabalho. 


\section{SUMÁRIO}

Página

RESUMO .............................................................................................. vi

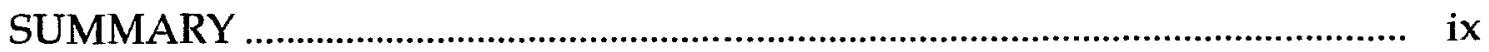

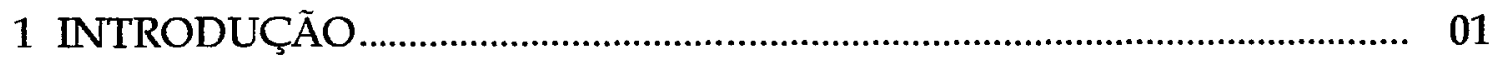

2 REVISÃO BIBLIOGRÁFICA ....................................................................... 06

3 MATERIAL E MÉTODO........................................................................... 29

3.1 Considerações Gerais....................................................................................... 29

3.2 O Plano de Desenvolvimento Florestal Sustentável - PDFS ......................... 30

4 RESULTADOS E DISCUSSĀO ............................................................ 40

4.1 As etapas do processo de planejamento anteriores à elaboração do PDFS ....... 41

4.1.1 O diagnóstico do setor a ser alterado ...................................................... 41

4.1.2. A política de desenvolvimento para o complexo que se deseja alterar ......... 44

4.2 As etapas do processo de planejamento concernentes à elaboração do PDFS... 45

4.2.1 A definição dos objetivos do PDFS............................................................. 45

4.2.2 Os objetivos do PDFS e a participação da população na sua definição .......... 46

4.2.3 A definição da metas do PDFS................................................................... 52

4.2.3.1 Aspectos qualitativos e quantitativos..................................................... 53

4.2.3.2 Os prazos de realização e a viabilidade política......................................... 53

4.2.4 A definição dos Programas do PDFS........................................................... 54

4.2.4.1 A especificação das metas dos Programas ................................................. 55

4.2.4.2 A definição dos órgãos executores do PDFS............................................ 56

4.2.4.3 Os recursos financeiros e suas implicações................................................. 56

4.2.4.3.1 A orçamentação e o orçamento-programa................................................ 57

4.2.4.3.2 Os recursos financeiros e a política econômica ..................................... 57

4.2.4.3.3 Instrumentos econômicos e a geração de recursos financeiros ................. 61

4.2.4.3.4 Instrumentos econômicos e incentivo ao plantio ................................... 71

4.3 As etapas do processo de planejamento posteriores à elaboração do PDFS ..... 79

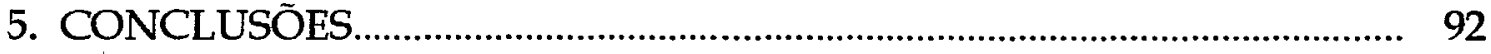

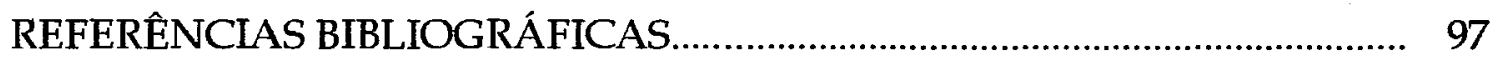




\title{
A MORTE ANUNCIADA DO \\ PLANO DE DESENVOLVIMENTO FLORESTAL SUSTENTÁVEL DO ESTADO DE SÃO PAULO
}

\author{
Autor: ROBERTO BRETZEL MARTINS \\ Orientador: Prof. Dr. ORIOWALDO QUEDA
}

\section{RESUMO}

Em 1993, A Secretaria de Estado de Meio Ambiente, do Governo do Estado de São Paulo, lançou o "Plano de Desenvolvimento Florestal Sustentável - PDFS" como uma estratégia de intervenção no setor florestal em um horizonte de 25 anos. Por meio de programas diferenciados, envolvendo atividades de fomento, de produção e de distribuição de mudas e sementes florestais, o Plano objetivava uma intervenção ativa para alterar o quadro de degradação dos recursos florestais nativos e atender a demanda de madeira para fins energéticos e de matéria-prima. A meta estabelecida era o plantio de quatro milhões de hectares de florestas, em um periodo de 25 anos.

Um plano, como o PDFS, constitui um documento de referência, orientador de um processo maior, sistematizado, que é o planejamento. $O$ planejamento é um processo de intervenção racional numa realidade sócioeconômica ou ambiental, que se destina a produzir um ou mais estados futuros desejados que não irão ocorrer a menos que se atue positivamente na direção desejada. Em outras palavras, o processo de planejamento caracteriza-se como um conjunto de etapas através do qual realizar-se-á uma determinada intervenção, no qual é indispensável a elaboração de um plano. Enquanto 
processo, o planejamento obedece a relações de interdependência que o identifica como um conjunto coerente de partes relacionadas entre si, facilitando o aumento da eficácia da intervenção e produzindo os resultados finais almejados.

O objetivo desta dissertação é analisar o PDFS enquanto um planejamento para o setor florestal paulista, identificando e discutindo a presença e o cumprimento de cada etapa necessária de um processo de planejamento. Dessa forma, é possível verificar as imperfeições relativas a condução deste processo, verificando se ele constitui um conjunto coerente de partes relacionadas entre si, necessário para produzir os resultados que a intervenção se propõe a realizar.

Para tanto, foi feita uma revisão bibliográfica sobre planejamento, a partir da qual foram estabelecidas as matrizes conceituais utilizadas como referência e a seqüência de etapas do processo de planejamento. Quanto ao PDFS, são apresentados os aspectos principais de seu conteúdo, sem tomar uma posição quanto aos conceitos e propostas exprimidos. Os elementos do Plano foram reordenados nessa apresentação para facilitar a sua comparação com as etapas de um processo de planejamento traçadas na revisão bibliográfica. Esta comparação foi a base da análise do PDFS, enquanto parte de um processo de intervenção.

Os resultados obtidos permitem identificar imperfeições nas etapas concernentes à elaboração do Plano, especificamente na definição de objetivos e metas sem o envolvimento dos executores da proposta, e na definição de Programas sem avançar em seu detalhamento. Nas etapas posteriores à elaboração do PDFS, identificou-se uma ausência de operacionalização do Plano, comprometendo a sua implantação e sua periódica avaliação, essenciais para que o processo de planejamento possa ter continuidade. 
A conclusão final é que o PDFS foi um resultado isolado, um Plano com um fim em si mesmo, que não fez parte de um processo mais amplo de intervenção, de um planejamento para o setor florestal paulista. 


\title{
THE ANNOUNCED DEATH \\ OF THE SUSTAINABLE FORESTAL \\ DEVELOPMENT PLAN
}

\author{
Author: ROBERTO BRETZEL MARTINS \\ Adviser: Prof. Dr. ORIOWALDO QUEDA
}

\section{SUMMARY}

In 1993, the Environment State Bureau from São Paulo State Government, launched the "Sustainable Forestal Development Plan (PDFS)" as an strategy of intervention in the forest sector in a 25 year span. Through different sorts of programs, involving distribution of seeds and molts, fomentation and production activities, the Plan aimed an active intervention to change the degradation situation of the natural forest resources and respond to the wood claim for energy purposes and as raw material. The established aim was the plantation of four million hectares of forest in 25 years.

A plan such as "PDFS" constitutes itself a reference document, guide for a bigger systematized process, which is the planning. Planning is a process of rational intervention in a social-economic or environmental reality in order to produce one or more desired future states that won't occur unless there's a positive action to the desired direction. In other words, the planning process is featured as a gathering of steps by which a certain intervention will take place, in which a plan of elaboration is fundamental. Once it is a process, the planning obeys the interdependence relations that identify it as a coherent set of parts 
related to one another, enabling the increase of efficacy on the intervention, producing the desired final results.

The aim of this dissertation is to analyze the "PDFS" while a planning for the São Paulo State forest sector, identifying and discussing the presence and the accomplishment of each necessary step of a planning process. Therefore it is possible to check the imperfections related to the process conduction, checking if it constitutes a coherent set of parts related to each other, which is necessary to produce the results that the intervention is willing to realize.

For all above mentioned, bibliographic review was made, from which the conceptual moulds used as reference were set up and the sequence of the steps of the planning process. Concerning to the "PDFS", the main aspects of its content are shown without showing a clear position about the expressed concepts and proposals. The elements of the Plan were reorganized in this presentation to ease its comparison with the steps of a planning process traced in the bibliographic review. This comparison was the basis of the analysis of the "PDFS" while part of an intervention process.

The obtained results make possible an identification of the imperfections in the steps concerning to the elaboration of the Plan, specifically in the definition of aims and goals without the involvement of the proposal executors as well as the definition of the Programs without further complimentary details. In the posterior steps after the "PDFS" elaboration, an absence of operational actions of the Plan was noticed, harming its implantation and its periodical evaluation that are essential for the continuity of the process planning.

The final conclusion is that the "PDFS" was an isolated result, a Plan with an end in itself, that is not part of a larger intervention process, of a planning for São Paulo forest sector. 


\section{INTRODUÇÃO}

As florestas são parte integrante dos sistemas de suporte da vida do Planeta Terra (IUCN, 1991). Cobrindo apenas 6\% da superfície terrestre, as florestas tropicais, ecossistemas complexos e frágeis que contém milhões de espécies animais e vegetais (Myers, 1988), fornecem uma vasta gama de recursos aos seres humanos.

Do ponto de vista ecológico, as matas influem no clima local e regional, agem como reserva da diversidade genética e estoque de carbono, contribuem para regenerar os solos e protegê-los contra a erosão, protegem as zonas situadas rio abaixo das inundações e do assoreamento (IUCN, 1984), mantendo uma certa regularidade dos regimes hídricos de água doce (Bascur, 1990).

As florestas oferecem uma vasta gama de produtos tais como madeira (para múltiplos usos), látex e resinas, ceras, gomas, óleos essenciais, fibras e elementos medicinais (IUCN, 1991). Quanto aos gêneros alimentícios, estes podem ser obtidos de árvores e arbustos que naturalmente crescem em florestas ou são cultivados ao redor da casa, tais como condimentos, frutas, e raízes. Representam ainda uma influência indireta em sistemas de produção, seja contribuindo para a alimentação e forragem dos animais nas estações de seca, seja aumentando a fertilidade do solo no qual ajudam a sustentar culturas anuais. 
Esta diversidade de produtos e "serviços" constitui um elo entre as florestas e a Segurança Alimentar ${ }^{1}$ para as populações que dela dependem (FAO, 1989). Os alimentos obtidos das árvores e florestas são contribuições fundamentais para a dieta de muitas famílias. Para muitas delas, os produtos coletados, processados e vendidos representam uma importante fonte de emprego e renda utilizada na compra de comida e para suprir outras necessidades básicas (FAO, 1989).

No entanto, mesmo com uma imensidade de benefícios, 180.000 quilômetros quadrados (quase $2 \%$ ) das florestas e matas tropicais espalhadas pelo globo são desmatados anualmente. Na América Latina, o desmatamento ocorre para dar lugar à criação de gado, à agricultura migratória e insustentável, à especulação imobiliária e a assentamentos não-planejados nas áreas adjacentes às novas estradas em construção, favorecidos por políticas implementadas para promover o crescimento econômico e a colonização da terra (IUCN, 1991).

No Brasil, o processo de devastação vem ocorrendo de maneira acelerada. A abertura de novos espaços (implicando no sacrifício da vegetação nativa) marcou profundamente a formação sócio-cultural do nosso povo, que passou a relacionar, compulsoriamente, a presença das matas ao atraso, e a sua eliminação ao progresso. A floresta era algo que precisava ser conquistado e dominado a qualquer custo, pois trazia pouco ou nenhum benefício direto. Ao contrário, era muitas vezes responsabilizada pela insalubridade das terras (Victor, 1975).

No Estado de São Paulo, estima-se que a cobertura vegetal original das matas correspondia a cerca de $80 \%$ de seu território (Troppmair, 1974). A devastação no Estado é intensificada a partir do surto cafeeiro (Victor, 1975) e, em 1907, as matas cobriam o equivalente a $58 \%$ do território, sendo que em 1973,

${ }^{1}$ Segurança alimentar tem sido definida pelo Comitê Mundial de Segurança Alimentar como o acesso econômico e físico à alimentação, por todas as pessoas, a qualquer momento (FAO, 1989). 
apenas 8,3\% do território apresentavam matas nativas (Serra Filho, 1975), decrescendo para 5,3\% vinte anos depois (Instituto Florestal,1993).

Atualmente, o Governo do Estado é detentor de muitas das áreas remanescentes, por meio de Parques, Reservas Biológicas e Estações Ecológicas, dentre outros. No entanto, cerca de um milhão de hectares da vegetação nativa remanescente encontra-se nas mãos de particulares ou empresas (Castanho, 1984). Estas áreas, apesar de serem, em sua maior parte, as últimas reservas de vegetação nativa no Estado, responsáveis pela manutenção do equilíbrio ecológico na região onde se encontram, são objetos de intensa pressão (Castanho, 1984).

Em grande parte, essas pressões decorrem de uma política de lucros imediatista vinculada ao desenvolvimento agropecuário que muitas vezes consideram estes fragmentos florestais como áreas não aproveitáveis. A tendência é a diminuição a níveis muito baixos dos recursos florestais, acarretando a depredação de outros recursos naturais renováveis, como o solo e as águas.

Para iniciar um processo de reversão deste quadro, os órgãos públicos têm procurado implementar políticas, em especial, políticas ambientais ${ }^{2}$. A elaboração destas políticas para o setor florestal (assim como qualquer outro setor ligado aos recursos naturais) deve considerar a produção e a manutenção florestal, visando a utilização sustentada dos recursos, para proporcionar tanto os processos ecológicos quanto a sobrevivência humana.

Entretanto, apenas um conjunto de políticas e princípios de ação não é suficiente para interromper o curso de depredação dos recursos florestais. Era

${ }^{2}$ Política é aqui entendida como sendo "grandes diretrizes e orientações que facilitam a consecução dos fins, objetivos e metas e condicionam o uso dos recursos e o desenvolvimento das atividades" (Botler, 1995). 
necessário que o Estado vinculasse as políticas para o setor a uma intervenção na realidade florestal.

Tal iniciativa ocorreu em 1993, quando a Secretaria de Estado do Meio Ambiente do Governo do Estado de São Paulo lançou o "Plano de Desenvolvimento Florestal Sustentável - PDFS" como uma estratégia de ação para o setor florestal em um horizonte de 25 anos. Sustentada em três grandes estratégias - a conservação, a utilização sustentada e a educação ambiental - a principal meta do PDFS era o plantio de cerca de quatro milhões de hectares de florestas de conservação e de produção.

Um plano, tal qual o PDFS, constitui num documento de referência, orientador de um processo maior, sistematizado, que é o planejamento. $O$ planejamento é um processo de intervenção racional na realidade sócioeconômica (Szmercsányi, 1979), que se destina a produzir um ou mais estados futuros desejados que não irão ocorrer a menos que se atue positivamente na direção desejada (Ackoff, 1981). Obviamente, se acreditássemos que os acontecimentos atuais fossem produzir um estado futuro desejado, não haveria a necessidade de se planejar. Só se planeja quando se percebe que algum estado futuro desejado não irá efetivamente ocorrer. $O$ planejamento baseia-se na crença de que o futuro pode ser melhorado por uma intervenção ativa no presente através da "definição de um futuro desejado e de meios eficazes de alcançá-lo" (Ackoff, 1981, p. 1).

Assim, o planejamento pode ser definido como um procedimento lógico capaz de auxiliar efetivamente os esforços de desenvolvimento econômico, social e ambiental (Carvalho, 1978) e, como tal deve ser um processo mais amplo, não se limitando apenas a formulação de planos e programas de desenvolvimento (Szmercsányi, 1979). Trata-se de uma intervenção gradativa, que compreende vários estágios interligados, e na qual os planos e programas 
constituem simples documentos de referência, apesar de indispensáveis (Szmercsányi, 1979).

Portanto, o Plano de Desenvolvimento Florestal Sustentável do Estado de São Paulo é um documento de orientação, inserido num processo de planejamento. O que se objetiva com esta dissertação é analisar o PDFS enquanto parte inerente a um planejamento para o setor florestal, identificando e discutindo eventuais imperfeições nas etapas de um processo de planejamento e que possam induzir ao não cumprimento de seus objetivos e metas. Com isso, o que se espera ao analisar o PDFS é saber se ele foi um resultado isolado, um Plano com um fim em si mesmo, ou se ele realmente faz parte de um processo mais amplo de intervenção no setor florestal paulista, por parte do Governo do Estado. Por isso é necessário conhecer o que é o planejamento, seus tipos, matrizes conceituais e as etapas de um processo de planejamento. 


\section{REVISÃO BIBLIOGRÁFICA}

Planejamento é um termo abrangente com diversos significados, variando de acordo com o autor utilizado. Assim, segundo Jara (1996), ele pode ser entendido como teoria, sistema, processo ou como um instrumento aplicável a diversos tipos de atividade. Seus objetivos são variados, e vão desde mudanças estruturais, a simples intervenções assistencialistas, e até mesmo à consolidação de uma determinada realidade.

Ao final do século $\mathrm{XIX}$, sua aplicação podia ser constatada em países capitalistas economicamente avançados. Utilizado pelo governo tanto em serviços voltados para o bem-estar da população (saúde, saneamento básico, educação), quanto no campo da infra-estrutura econômica (energia, transporte, comunicação), era praticado de maneira espontânea quando da previsão e execução orçamentária governamental mas, ainda, sem receber a denominação de planejamento (Szmercsányi, 1979).

Apenas durante a primeira Grande Guerra alguns países o utilizaram visando solucionar problemas econômicos gerados pelo conflito, "dando origem a formas embrionárias do planejamento econômico centralizado" (Szmercsányi, 1979 , p.9). Solucionados os problemas, foram em sua maioria abolidas após a guerra.

Na União Soviética a planificação econômica e social teve início logo depois da revolução bolchevique de 1917. Os primeiros planos econômicos de uma nação inteira, registrados, ocorreram na Rússia Soviética, com o objetivo de 
abastecer a população com pão e as indústrias com carvão, em 1919 e 1920 (Efimov \& Anchishkin, 1972).

A partir destas experiências, o planejamento socialista soviético foi sendo aperfeiçoado e gradativamente ampliado para outros setores da economia. $\mathrm{O}$ desenvolvimento de uma base teórica, elaborada a partir de experiências empíricas, possibilitou a implantação de planos mais consistentes e de longo prazo, os chamados planos qüinqüenais, responsáveis pela construção da economia soviética (Efimov \& Anchishkin, 1972; Szmercsányi, 1979). Nos países de economia capitalista, sua introdução em bases permanentes ocorreu logo após a crise econômica mundial de 1929-1933 (Efimov \& Anchishkin, 1972; Szmercsányi, 1979), quando países como a Alemanha o associaram a políticas keynesianas de combate à depressão. Entretanto, sua utilização mais ampla na economia ocorreu apenas depois da Segunda Guerra Mundial (Carvalho, 1978; Szmercsányi, 1979), com os governos induzindo e regulamentando as atividades econômicas do setor privado. Seguindo uma planificação sistemática, tais países conseguiram reestruturar suas economias que, após o conflito, estavam completamente destruídas.

Diante do sucesso pós-guerra, o planejamento passou a ser empregado visando um desenvolvimento econômico acelerado, com uma maior intervenção do Estado nas áreas econômica e social. Tal medida justificava-se, segundo Efimov \& Anchishkin (1972), pela necessidade de estabelecer objetivos de caráter nacional. Assim, nas economias capitalistas centrais, predominava o chamado Welfare State "voltado para a produção e distribuição de bens e serviços sociais desmercantilizados e garantidos a todos segundo critérios universalistas, configurando portanto direitos sociais dos cidadãos ${ }^{3 \prime \prime}$ (Draibe, 1995, p.3).

3 "Em tal sistema tendem a mesclar-se mecanismos de renda mínima; regimes previdenciários gerais que oferecem uma base comum de benefícios de aposentadorias e pensões relativamente 
Tal situação perdurou até o início da década de 80 , quando algumas economias capitalistas centrais, em especial a dos Estados Unidos e a da Inglaterra, deram início a uma profunda reestruturação em suas políticas sociais com reflexos diretos na redefinição do alcance e dos limites da intervenção estatal. O Estado ainda mantém a sua capacidade de intervenção, mas altera a sua natureza (Braga, 1998).

Assim, dá-se início à adoção de procedimentos como privatização, descentralização, flexibilização e introdução de instrumentos de mercado (por exemplo, a terceirização). Isto "não significa desmantelar o aparato estatal mas focalizá-lo, escolher o que é essencial e crítico, combinar adequadamente a capacidade institucional estatal com as ações efetivamente prioritárias" (BIRD, citado por Silva, 1998, p.16). Estas modificações fazem parte de um contexto mais amplo de mudanças no Estado e de fortalecimento do ideário neoliberal, globalização produtiva e financeira, reestruturação econômica (nos países centrais) e ajuste/crise fiscal (na periferia) (Braga, 1998).

Segundo Silva (1998), na América Latina o movimento estrutural de redefinição da natureza, do alcance e dos limites da intervenção estatal produziu um forte impacto, adquirindo porém significado completamente distinto. Em lugar de mudança da natureza da intervenção do Estado, o que se assiste é a uma desmontagem do próprio Estado.

No caso brasileiro, estas tendências são implementadas na passagem dos anos 80 para os anos 90, abandonando-se o ideal desenvolvimentista ${ }^{4}$,

independentes das contribuições pretéritas; equipamentos coletivos públicos gratuitos para a prestação universal de serviços essenciais, especialmente os de saúde e de educação compreensiva e programas de assistência social apoiados na concepção de direito a condições básicas de vida" (Draibe, 1995, p.3)

${ }^{4}$ "Entre o final da Segunda Guerra e meados dos anos 70 predomina na América Latina o ideal do nacional desenvolvimentismo, um movimento no qual estes países, se aproveitando das brechas e contradições das economias centrais, fazem um movimento de ruptura com o modelo de "desenvolvimento para fora" e, a partir de uma atuação decisiva do Estado, promovem um processo de industrialização. O desenvolvimento é então a questão central no Brasil que busca, através da industrialização, investir no sonho de superação de sua inserção subordinada na economia mundial" (Braga, 1999,p.2). 
enquanto o questionamento da intervenção estatal e da desmontagem dos mecanismos de planejamento ganham força. Questões como redução do tamanho do Estado, descentralização e privatização ocupam lugar de destaque na agenda governamental como respostas às pressões externas para a adoção de políticas estruturais neoliberais (Braga, 1998).

Portanto, a partir da década de 80, o modelo de desenvolvimento do complexo sócio-econômico em países de economia capitalista não mais ocorre através da indução por uma intervenção planejada pelos governos. Reforça-se o credo na iniciativa privada e nas forças livres do mercado como "mecanismos automáticos e eficientes de regulação que tornariam desnecessários o planejamento ou que poderiam ser deixados à improvisação" (Huertas, 1996, p.13). Ganha corpo o processo de redefinição do alcance e dos limites da intervenção estatal e da utilização do planejamento.

Ainda assim, os governos de praticamente todos os países adotam algum tipo de planejamento econômico, social ou ambiental. Apesar das economias nacionais estarem sujeitas, ainda hoje, a alguma modalidade de intervenção governamental, isso não quer dizer que o planejamento sócioeconômico implica, necessariamente, em uma centralização das decisões pelo Estado.

Todos os sistemas econômicos atualmente combinam planejamento e economia de mercado, uma vez que, segundo Huertas (1996) o mercado não regula de maneira satisfatória o processo econômico e menos ainda os aspectos sociais do processo econômico. Ao Estado, utilizando-se do planejamento, cabe a função de corrigir tais deficiências. Assim, as atividades descentralizadas da iniciativa privada e as atividades coletivas da iniciativa governamental são complementares, podendo ser combinadas de várias maneiras (Efimov \& Anchishkin, 1972; Szmercsányi, 1979). 
Com a adoção da política econômica neoliberal - e de conceitos como privatização e terceirização -, atualmente a iniciativa privada vem assumindo, em vários setores da economia, as atividades que até então eram de responsabilidade governamental. Assim, as atividades do setor público na maior parte dos países não é mais orientada por um planejamento alocativo.

Segundo Szmercsányi (1979), planejamento alocativo é aquele em que o Estado tem o poder de adotar e pôr em prática decisões por meio de sua própria organização político-administrativa, alterando o complexo sócio-econômico sempre que o desejar. É o tipo de planejamento em que o Estado "exerce um controle amplo e direto sobre os fatores de produção por ele empregados, tanto no que se refere ao volume de recursos a investir, como no que diz respeito aos custos de investimento e manutenção desses recursos"(Szmercsányi, 1979, p.6). Como exemplo de utilização desse tipo de planejamento pode-se citar a ação do governo brasileiro na promoção de desenvolvimento econômico entre as décadas de 30 e 70.

O que se observa com a adoção da política econômica neoliberal nos anos 90, são os governos influenciando a adoção e execução de determinadas decisões por parte da iniciativa privada, utilizando-se para isso de instrumentos como tributos, subvenções, empréstimos subsidiados e incentivos fiscais. É um controle indireto, que se dá pelo emprego de instrumentos políticos e econômicos impostos ao mercado. O emprego de instrumentais variados da política econômica por parte do governo, de maneira programada, influenciando as decisões da iniciativa privada, é conhecido como planejamento indicativo (Lafer, B. 1970; Szmercsányi, 1979; Walinsky, 1965). Ele possibilita ao Governo manter sob controle o quadro institucional, alterando as regras da política econômica, social e ambiental toda vez que as circunstâncias assim o exigirem. 
De acordo com Szmercsányi (1979), se há uma eficácia no planejamento indicativo, ela vem exatamente do fato das atividades da iniciativa privada estarem condicionadas e coordenadas pelo quadro institucional ao qual estão inseridas. As modificações deste, por meio das ações deliberadas do Governo, regula o comportamento dos agentes econômicos no capitalismo (Walinsky, 1965), assumindo um papel de catalizador ou estabilizador das forças do mercado (Efimov \& Anchishkin, 1972). O planejamento não se opõe ao mercado se utilizado como instrumento de complementação e correção dos pontos em que as suas deficiências são mais exarcebadas (Huertas, 1996).

Ainda que atualmente a utilização do planejamento seja mais restrita que em sua "fase áurea", do imediato pós-guerra ao final da década de 70 , sua importância não pode ser desprezada como instrumento de atuação estatal, independentemente do regime político-econômico, amplitude ou objetivos.

É precisamente a diversidade e a universalidade do planejamento que permitiu o desenvolvimento de diferentes matrizes conceituais, que definem, de formas alternativas, e por vezes contraditórias, o que é o planejamento e qual a sua relação com o processo político.

Szmercsányi (1979) diferencia os conceitos de planejamento a partir de uma associação entre o planejamento e o poder, identificando três principais matrizes.

Na primeira matriz, o planejamento é concebido como um instrumento neutro, não político, facilitador da execução das estratégias de desenvolvimento sócio-econômico e ambiental, que apenas racionaliza os processos de tomada de decisão. O planejamento constitui um simples instrumento técnico da política econômica e social, onde as estratégias, assim como os objetivos, lhe são impostas ao invés de serem geradas durante o processo de planejamento.

Na segunda, o planejamento constitui um método de ação no campo da política econômica e social. Apesar de sua utilização com objetivos pré- 
determinados, as estratégias e as decisões que daí derivam são profundamente influenciadas durante o próprio processo de planejamento. Assim, a política econômica e social são orientadas a partir da aplicação do planejamento.

Segundo a terceira matriz, o planejamento constitui todo um processo de intervenção racional do Estado na vida sócio-econômica do país. "Trata-se de uma intervenção ampla e profunda, que envolve a própria formulação dos objetivos e da estratégia da política econômica e social" (Szmercsányi, 1979, p.4).

A diferença básica existente entre as três matrizes encontra-se na definição dos objetivos e na tomada de decisões. Na primeira matriz, tanto os objetivos quanto as decisões são impostas e o planejamento é utilizado como processo de execução. Na segunda matriz, tanto os objetivos quanto a tomada de decisão são impostas, mas são influenciados ou revisados durante a sua execução pelo processo de planejamento. Já na terceira matriz, objetivos e decisões não são impostos, mas surgem da aplicação do processo de planejamento.

O Autor aponta que dentre essas três matrizes, a terceira é aquela que possui um conceito mais amplo e que, portanto, possibilita avaliar o planejamento segundo o contexto sócio-econômico a que se aplica. Concordando com o Autor, esta terceira matriz será utilizada como referencial neste trabalho.

Uma outra forma de dividir os conceitos de planejamento em diferentes matrizes, ou concepções, é aquela adotada por Arroyo (1996).

Segundo Arroyo (1996), uma primeira concepção, denominada normativa ou tradicional, entende a realidade como sendo estática, pois é passível de ser apreendida de maneira inequívoca e absoluta por quem possui o conhecimento técnico. O planejamento concebido a partir desta visão normativa resulta em planos de ação tecnicamente corretos, mas politicamente inadequados e de difícil implantação, porque contempla o ponto de vista apenas 
de quem planeja e não incorpora a visão dos outros atores sociais que serão envolvidos na execução do planejamento.

A segunda concepção identificada pelo Autor é a estratégica, que entende a realidade como dinâmica, permanentemente em conflito. Entende-se os diferentes atores envolvidos como oponentes, sem possibilidade de conviver no mesmo espaço. É o planejamento introduzido no mundo empresarial, que busca sucesso na disputa de mercado (Arroyo, 1996).

A terceira concepção é a participativa, que reforça a construção coletiva do conhecimento sobre uma determinada realidade. Deste planejamento resulta a democratização, cooperação e co-responsabilidade na tomada de decisão sobre as ações mais adequadas e na sua implementação (Arroyo, 1996).

Por fim, a quarta concepção é a estratégica situacional, e foi desenvolvida pelo economista chileno Carlos Matus ${ }^{5}$ no final da década de 70. Ela sintetiza as concepções anteriores, pois entende a realidade em permanente conflito, movimento e mudança. Situa os diferentes atores sociais e suas leituras distintas, tentando construir um olhar comum no processo de diálogo entre eles. (Arroyo, 1996; Rique, 1996).

Dentre as quatro concepções identificadas por Arroyo (1996), a quarta é por ele defendida como a mais adequada porque trabalha com duas dimensões complementares: a estratégica e a situacional. Pela dimensão estratégica, esta concepção não ignora o conflito existente entre os diferentes atores sociais, mas todo o processo de ação é orientado por este conflito de interesses. E pela dimensão situacional, esta concepção parte do princípio de que não existe uma leitura única e correta da realidade, mas que diferentes atores têm visões diferentes da realidade a partir da sua perspectiva ou situação. Por entender que

${ }^{5}$ Carlos Matus é o criador do Planejamento Estratégico Situacional (PES). Ao longo da dissertação, citarei Matus sempre que me referir ao PES. No entanto, por não ter encontrado uma bibliografia do próprio Matus, quando me referir ao PES, o mencionarei citando os autores dos quais extraí o conteúdo utilizado. 
estas dimensões devem ser contempladas durante o processo de planejamento, essa concepção também será utilizada como referência no presente trabalho.

Outros autores e suas concepções também poderiam ser citados. É o caso de Carvalho (1976), que apresenta três concepções ou abordagens distintas quando se discute a necessidade e o conceito de planejamento: a abordagem psicológica, a abordagem econômica e a abordagem política e social.

Utilizarei como base conceitual de planejamento a terceira matriz elaborada por Szmercsányi (1979) e o Planejamento Estratégico Situacional (PES) desenvolvido por Carlos Matus (Arroyo, 1996). Para ambos os conceitos, os objetivos e decisões năo devem ser impostos aos atores sociais que participarão direta ou indiretamente dos resultados e da implementação do planejamento, e sim surgir durante a sua aplicação. A principal diferença entre os conceitos acima citados está na maneira com que tais objetivos são definidos e sua relação com a população. Para Szmercsányi (1979) a definição dos objetivos é elaborada pelos planejadores e posteriormente apresentada à população para ser discutida, enquanto, para Arroyo (1996), os objetivos são definidos conjuntamente entre a população e os planejadores. Esta diferença será aprofundada mais à frente.

A opção por utilizar tais conceitos como base neste trabalho está no fato da aplicação do planejamento, conforme aqui entendido, implicar não só em alterações econômicas, mas sociais e até mesmo políticas. Pois um planejamento destinado ao desenvolvimento provoca mudanças nos mais diversos setores da sociedade, implicando, muitas vezes, em alterações das relações sociais e políticas. Portanto, a população deve desempenhar nesse processo o seu papel, por meio de suas organizações, participando da determinação dos objetivos da política econômica, social e ambiental, além da execução e acompanhamento de um processo que irá lhes atingir diretamente. (Carvalho, 1978; Walinsky, 1965). 
Isso posto, o planejamento pode ser definido como sendo um procedimento lógico capaz de auxiliar efetivamente os esforços de desenvolvimento econômico, social e ambiental (Carvalho, 1978). Ele tem, portanto a função de descobrir as exigências atuais e os potenciais da sociedade em relação a bens materiais e serviços, bem como determinar as fontes, os métodos e os prazos a serem utilizados, visando alcançar as alterações desejadas numa determinada realidade (Efimov \& Anchishkin, 1972).

Neste contexto, planejamento é um recurso metodológico, um instrumento de conhecimento, mediador entre o que se deseja e o que é possível (Arroyo, 1996). “É um procedimento que facilita a apropriação da realidade com seus desafios e demandas e permite tomar decisões sobre a maneira como se deseja intervir na realidade para alterá-la" (Arroyo, 1996, p.14), ou para conservá-la.

A despeito da diversidade conceitual, o planejamento sócio-econômico obedece a determinados procedimentos, constituindo um método de aplicação, um processo de dar racionalidade à ação (Almeida et al., 1983). Assim, para analisar uma determinada experiência de planejamento, não basta entender o que ele é e suas diferentes concepções. É necessário também ter uma noção do seu funcionamento, processo e forma de utilização, que são elaborados em função do estágio de desenvolvimento sócio-econômico e o regime político de cada país (Szmercsányi, 1979).

Por exemplo, Almeida et al. (1983) aponta duas principais vertentes do processo de planejamento dentre as diversas linhas existentes. $\mathrm{Na}$ primeira, denominada demanda, estuda-se a problemática sócio-econômica da população para definir os objetivos e metas a serem alcançados. Na segunda, denominada oferta, "estuda-se as características do meio em que se desenvolve a atividade humana, definindo as possibilidades atuais e potenciais de satisfazer a demanda" (Almeida et al., 1983, p.15). 
Já Ackoff (1981) identifica dois processos de planejamento, o tático e o estratégico. $O$ planejamento tático caracteriza-se por ações a curto prazo, mais restritas, destinando-se a escolher os meios pelos quais se tentará atingir objetivos específicos. O planejamento estratégico, por sua vez, caracteriza-se por decisões de efeitos duradouros, a longo prazo, destinado tanto à formulação de objetivos, quanto à escolha de meios para atingi-lo.

Carvalho (1978) resume o processo de planejamento como sendo:

“... planos, programas e projetos de desenvolvimento econômico e social, como o conjunto de atividades, dispositivos institucionais, medidas administrativas ou normas legais, que permitam ou facilitem a maior compreensão por parte dos diferentes públicos, dos objetivos, das formas de execução das responsabilidades que deverão ser assumidas por parte dos interessados, para a eficiente consecução dos programas e projetos de desenvolvimento" (Carvalho,1978, p.31).

A despeito de sua diversidade, todo planejamento, como processo de racionalização da ação, segue etapas básicas. A forma de utilização dessas etapas ocorre de maneira diferenciada entre as diferentes abordagens de planejamento, seja dando maior ou menor enfoque a uma ou outra etapa, seja excluindo alguma delas.

Em outras palavras, o processo de planejamento caracteriza-se como um conjunto de etapas pelo qual irá se realizar uma determinada intervenção. Portanto, enquanto um processo, ele obedece a relações de interdependência que o identifica como um conjunto de partes coordenadas entre si. Um conjunto coerente, que deverá produzir resultados finais ou objetivos que facilitem o aumento da eficácia da intervenção. 
O conjunto de fases ou etapas que caracterizam o processo de planejamento varia entre os diferentes autores porque pode-se optar por maneiras diferentes de se subdividir as decisões que devam ser feitas. Desde que etapas básicas e decisões importantes estejam presentes, as diversas maneiras de se dividir um plano em partes passa a ser uma questão de preferência pessoal, ou até mesmo de estilo (Ackoff, 1981).

Por exemplo, Carvalho (1978) identifica quatro etapas que caracterizam o processo de planejamento:

1. conhecimento da realidade por meio de diagnóstico e prognóstico dos principais indicadores explicativos de uma situação problema;

2. estudo de diferentes alternativas de intervenção, visando otimizar a estratégia política estabelecida e os recursos financeiros;

3. implantação das decisões tomadas tendo em vista transformar alguma situação, estando intimamente ligada ao conjunto de proposições efetuadas na fase anterior $e_{\text {; }}$

4. conjunto de processos ou sub-processos de acompanhamento, controle e avaliação de desempenho de determinadas operações.

Ackoff (1981), por sua vez, identifica cinco etapas:

1. especificação de objetivos e metas;

2. escolha de políticas, programas, procedimentos e práticas através dos quais se tentará atingir os objetivos;

3. determinação dos tipos e quantidades de recursos necessários, como eles devem ser gerados ou obtidos e como eles devem ser alocados às atividades;

4. determinação de procedimentos para a tomada de decisões e de uma maneira de organizá-los para que o plano possa ser executado e;

5. determinação de procedimentos para antecipar ou detectar erros no plano ou falhas na sua execução e para prevenir ou corrigir continuamente estes erros e estas falhas. 
Também Almeida et al. (1983) identifica cinco etapas no processo de planejamento:

1. identificação e descrição do sistema;

2. definição dos problemas;

3. geração de soluções que satisfaçam os objetivos sem violar as restrições do sistema;

4. seleção da solução que melhor satisfaça os objetivos através de um processo de avaliação, no qual terá de dar entrada a certas apreciações subjetivas e juízo de valores e;

5. execução e controle.

Szmercsányi (1979) apresenta uma divisão em seis estágios ou etapas que compõem um processo de planejamento. É uma divisão mais abrangente, minuciosa e explicativa, que inclui e complementa aquelas idealizadas pelos autores acima citados. Por este motivo, o aprofundamento do processo de planejamento e cada uma de sua etapas na dissertação presente, seguirá as divisões feitas por Szmercsányi (1979), a saber:

1. diagnóstico da evolução do complexo sócio-econômico, setor ou sistema que se pretende influenciar através do planejamento;

2. formulação de uma política de desenvolvimento para o complexo;

3. elaboração do plano propriamente dito;

4. execução do plano;

5. avaliação periódica dos resultados obtidos e;

6. progressiva reformulação do diagnóstico, da política de desenvolvimento, dos objetivos e dos instrumentos do plano.

O planejamento é iniciado, necessariamente, com um diagnóstico do setor no qual se quer intervir, pela simples razão de que "apenas se pode planejar adequadamente aquilo que se conhece"(Szmercsányi, 1979, p.13). Assim, um planejamento conseqüente deve estar calcado em um diagnóstico 
seguro, que conheça a realidade sócio-econômica em que se quer intervir, sem o qual o mesmo poderá se tornar inviável.

Tal diagnóstico deve reconhecer as variáveis relevantes para a compreensão da estrutura e funcionamento do setor a ser alterado (Almeida et al., 1983). Sendo executado por meio de pesquisas e levantamentos, ele deve obter indicadores explicativos da situação atual (Carvalho, 1978), além de informações sobre a sua evolução histórica e tendências que possam resultar num prognóstico acerca da evolução futura do setor, sem levar em conta possíveis efeitos da intervenção que se pretende elaborar (Szmercsányi, 1979).

É uma pesquisa feita com rigor e profundidade científica, elaborada por uma equipe de especialistas que deve retratar a situação atual do setor, contribuindo com uma teoria explicativa e evidenciando a consistência desta teoria com o que é observado.

Entretanto, nenhum plano real é formulado apenas com base em diagnósticos (Huertas, 1996). Completado o diagnóstico, o passo seguinte é a formulação de uma política de desenvolvimento para o complexo sócioeconômico, cuja evolução futura se pretende planejar. Se o objetivo é garantir a continuidade da política formulada ao longo do tempo, é preciso que ela esteja orientada para transformações estruturais que propiciem uma maior participação de toda a sociedade nos frutos da intervenção, conferindo-lhe legitimidade.

No entanto, por ser apenas um método, um instrumento, o planejamento pode ser utilizado tanto para diminuir desigualdades de determinados grupos sociais, como estar condicionado politicamente e ser utilizado como uma manobra pelos grupos políticos dominantes (Cardoso, 1970). 
Segundo Efimov \& Anchishkin (1972), os aspectos específicos do planejamento e a possibilidade de se fazer dele uma força capaz de transformar a sociedade vêm da escolha das diretrizes políticas a serem adotadas.

A própria decisão de planejar é política, pois é uma tentativa de alocar explicitamente recursos e, implicitamente, valores, por meio do processo de planejamento e não pelos tradicionais ${ }^{6}$ mecanismos do sistema político (Lafer, $C$. 1970). As prioridades e a distribuição de recursos passam a ser baseadas num modo racional de proceder, a partir do qual se diagnosticam as carências, se escolhem os objetivos e se definem os meios a serem empregados, segundo regras e procedimentos elaborados por um conjunto de técnicos (Cardoso, 1970).

Ainda assim, por mais que a intervenção proposta se baseie em dados cientificamente coletados e os objetivos traçados sigam normas técnicas, existem valores, muitas vezes não explicitados, a partir dos quais os técnicos formulam os planos. Esses valores precisam estar claros, bem como ser debatidos pela sociedade, para que se possa orientar o planejamento na obtenção de transformações estruturais que propiciem maior participação de toda a sociedade nos frutos da intervenção.

A política de desenvolvimento de um complexo sócio-econômico é, portanto, composta por um conjunto de valores e diretrizes que irão dar forma a um determinado programa de ação governamental e condicionar a sua execução. Valores estes que, no mais das vezes, favorecem interesses do(s) grupo(s) político(s) que estão à frente do poder institucionalizado. Desta forma, os valores que conformam as políticas precisam ser explicitados para possibilitar o debate e o amadurecimento político da sociedade.

${ }^{6}$ Segundo Cardoso (1970), os mecanismos tradicionais a que se refere Lafer, C. (1970) são a continuidade do sistema político através do sistema eleitoral e de distribuição de recursos baseado, por exemplo, nas esferas de influência (Estado, partidos políticos e administração). 
Uma vez realizado o diagnóstico e definida a política para o setor, procede-se à elaboração do plano, que tem início com a escolha de seus objetivos e instrumentos. O planejamento entendido como a mera elaboração de planos e programas não é desejável segundo Szmercsányi (1979). Apesar de indispensáveis para que haja um planejamento, os planos e programas fazem parte do processo e constituem documentos de referência, mas não são o planejamento em si. Tanto o plano, quanto os programas e os projetos são documentos orientadores de um processo maior, sistematizado, que é o planejamento (Carvalho, 1978).

O plano é um meio para comunicar certas informações e coordenar as ações para atingir as metas previstas, constituindo-se "num artifício para registrar determinadas decisōes, tendo uma missão coordenadora de objetivos e receptora da participação pública nas decisões, mas os seus determinantes não são rígidos"(Almeida et al., 1983, p.15).

Um plano significa, antes de tudo, a redação de um texto (documento) que consubstancie os objetivos a serem alcançados pelos diversos setores da economia ou da sociedade; as diretrizes; a alocação dos recursos e os prazos necessários para alcançar os objetivos (Carvalho, 1978).

A elaboração do Plano propriamente dito, inicia-se ao confrontar as informações obtidas a partir do diagnóstico com os princípios definidos na política de desenvolvimento, obtendo-se um conjunto de objetivos para a evolução futura do setor que se pretende submeter ao planejamento. Tais objetivos podem ser tanto quantitativos quanto qualitativos (Szmercsányi, 1979).

É neste ponto que se encontra a diferença entre a base conceitual de planejamento da terceira matriz identificada por Szmercsányi (1979) e o Planejamento Estratégico Situacional (PES) desenvolvido por Carlos Matus (Arroyo, 1996): a maneira como tais objetivos são definidos e a sua relação com o momento em que acontece a participação dos atores sociais. 
Para Matus (Huertas, 1996), a única etapa do processo de planejamento em que não necessariamente ocorre a participação da população, é a etapa do diagnóstico. Ela é uma investigação que deve retratar uma realidade sem representar nenhum ator social, que "corresponda a um parecer fundamentado, embora em certa medida também subjetivo, de uma equipe de especialistas" (Huertas, 1996, p.34). O diagnóstico é uma pesquisa rigorosa e com profundidade científica e, mesmo que no produto desta pesquisa esteja incutido a subjetividade do pesquisador, ela não dará origem diretamente a um plano.

São os indivíduos, os atores sociais que serão envolvidos na execução do planejamento e suas diferentes percepções e perspectivas da realidade que irão processar as informações do diagnóstico e a partir do qual definirão seus interesses e objetivos, sobre os quais estarão incutidos juízos de valores. Ou seja, os diversos atores sociais são os responsáveis pela formulação da política e pela escolha dos objetivos. Assim, mesmo que o pesquisador apresente informações com subjetividade ou crie explicações para o problema em questão, isso não necessariamente irá influenciar o plano, uma vez que os atores sociais irão interpretá-las a partir de sua leitura.

Para Szmercsányi (1979), quem define a política e os objetivos são os planejadores. Porém, antes de serem transformados em metas, os objetivos definidos pelos planejadores deverão ser colocados para apreciação e discussão, não apenas dos órgãos encarregados pela execução do plano, mas às populações, grupos ou indivíduos que, direta ou indiretamente, estão ou estarão envolvidos no processo de planejamento, ou sofrerão os efeitos da intervenção nele programada. É neste momento que será realizada a discussão dos objetivos elaborados pelos planejadores e os objetivos e valores dos atores sociais envolvidos.

Se os objetivos propostos para o plano não corresponderem às aspirações e às reais necessidades daqueles que estarão envolvidos na sua 
execução, tal plano não encontrará respaldo e sua implementação sofrerá resistências tendendo, até, a tornar-se inviável (Szmercsányi, 1979). Nesse sentido, a população desempenha um papel de autora, executora e beneficiária do processo de planejamento. Mesmo aqueles que não sejam agentes executores diretos dos objetivos dos planos, serão atingidos pelas medidas de intervenção em quaisquer que sejam os níveis e camadas sociais (Carvalho, 1978).

Mas independe de seguir os princípios constantes da matriz teórica identificada e defendida por Szmercsányi (1979) ou do Planejamento Estratégico Situacional desenvolvido por Matus (Arroyo, 1996), a fase de definição dos objetivos do plano deve enfrentar dois aspectos fundamentais que se não forem contemplados no processo do planejamento podem comprometer a sucesso de sua implementação.

O primeiro diz respeito à obtenção de um "consenso político" com relação aos objetivos sociais básicos a serem alcançados com a implementação da intervenção. Como conciliar a multiplicidade de objetivos e aspirações de grupos de interesse tão diversos, como classes de trabalhadores e classes de proprietários, para orientar a planificação?

Recorrendo a um retrospecto histórico, autores como Cardoso (1970), afirmam ser possível a obtenção de um consenso mínimo. Segundo este Autor, na época do pós-guerra, a França construiu gradualmente um consenso político para a implantação do processo de planejamento, por meio da participação crescente de diversos grupos na definição das metas e na formulação do plano. Já na extinta União Soviética o "consenso político" foi obtido revolucionariamente, pela parte da sociedade que venceu.

Cardoso (1970) aponta que, no Brasil, este "consenso político" esbarra num sistema político que reflete uma estrutura social. De um lado trabalhadores que, quando não estão excluídos do cenário político, são representados por organizações intermediárias como partidos, sindicatos, associações. E de outro, 
as classes proprietárias, representadas por organizações fluídas e politicamente fracas. Em ambas, suas estruturas de representação não dispõem de meios para agir coerentemente, nem das informações necessárias para formar uma idéia dos seus interesses comuns e capaz de permitir a definição e redefinição de seus interesses e propósitos.

Atingir um "consenso político" remete, portanto, a um trabalho contínuo e de longo prazo. E, mesmo assim, as chances de sucesso em obter tal consenso não são garantidas e podem falhar. Desse modo, o planejamento deve conseguir, no mínimo, uma aceitação razoável em relação aos objetivos básicos da intervenção, para que os indivíduos assumam parte ativa e avaliem o valor da mesma no conjunto de esforços empreendidos pelo Estado (Carvalho, 1978).

O segundo aspecto fundamental da fase de definição dos objetivos do plano, diz respeito às formas de comunicação entre a população e os planejadores. Como obter um "consenso político" ou, no mínimo, uma aceitação razoável entre os objetivos básicos da intervenção, se não houver canais de comunicação eficientes para a troca de informações entre Governo e população? Uma comunicação eficiente e contínua é uma condição básica para a elaboração de um planejamento que seja eficiente. É a maneira de trazer as decisões a serem tomadas para o debate, propiciando os meios para sua interpretação e compreensão.

Saber trabalhar com os diversos atores sociais com as mais variadas leituras e intenções de ações demanda uma construção coletiva na diferença e co-responsabilidade nas decisões (Arroyo, 1996; Huertas, 1996). Ao planejador, portanto, cabe a função de catalisar o processo, trazendo à sociedade as informações para a definição de seus interesses, o conhecimento de suas necessidades e a disponibilidade dos meios de organização para lutar por seus objetivos. Isso traz à discussão os diversos conhecimentos provenientes dos atores sociais que apresentam leituras distintas a partir de sua situação, 
perspectiva ou ótica (Arroyo, 1996), característica básica da concepção estratégica situacional de planejamento.

O conflito existente nestas opiniões diversas, deverá ser lapidado visando a construção de objetivos que orientem o planejamento. Mais do que isso, o conflito estimula a debate entre os diversos atores sociais e torna o planejamento um recurso de fortalecimento político, estimulando a discussão, as decisões e as ações a serem tomadas.

Tendo obtido um consenso ou uma aceitação mínima quanto aos objetivos dos planos, são estabelecidas as metas e escolhidos os instrumentos mais adequados para a execução do plano. É nesse momento que se passa à definição e elaboração de documentos (programas, sub-programas, projetos e sub-projetos) que permitirão uma visão de conjunto do elenco de decisões que permitam uma intervenção coordenada e supostamente apoiada em critérios técnicos (Carvalho, 1978).

As tarefas para a consecução dos objetivos definidos ao longo do processo de planejamento podem ser agrupadas em três fases: uma fase macro, uma fase intermediária e uma fase micro (Tinbergen, 1975).

Os procedimentos básicos da fase macro, dizem respeito à definição dos objetivos e instrumentos do padrão desejado para o complexo ou setor que se quer planejar numa escala macroeconômica. Trata-se das etapas até aqui descritas.

$\mathrm{Na}$ fase intermediária os objetivos do plano tornam-se mais concretos, mediante a decomposição do complexo a se alterar, em um certo número de setores ou regiões (Tinbergen, 1975). Para cada setor ou região, serão elaborados 
programas $^{7}$ com conteúdos e objetivos diversos, que são detalhados e quantificados em termos físicos e financeiros (Szmercsányi, 1979).

Assim, em um programa, deve constar as metas físicas, especificando prazos e localização, além do estabelecimento dos recursos, cronograma de implantação e organismos executores. Deve incluir, também, estudos de coerência entre as metas e os recursos disponíveis (Carvalho, 1978).

Como parte integrante de um plano e dentro do contexto do planejamento, o programa seria o resultado final da fase de tomada de decisões, tendo em vista o melhor uso dos recursos econômicos (Carvalho, 1978) para a consecução dos objetivos da intervenção, traçados durante o desenvolvimento das fases anteriores dentro do processo de planificação.

A terceira fase, ou microfase, é a etapa do planejamento na qual ocorre a subdivisão mais detalhada (Tinbergen, 1975) dos objetivos e das metas. Ela é estruturada paralelamente à programação setorial ou regional, e refere-se aos projetos que constituem a menor unidade no processo de planejamento (Szmercsányi, 1979).

Os projetos constituem objetos mais concretos para o planejamento que os programas e, se bem preparados, os dados disponíveis são mais exatos e detalhados. São também um importante instrumento para a análises mais precisas, o que pode conduzir a uma melhora na informação disponível para a avaliação do plano (Tinbergen, 1975).

Apesar de serem instrumentos básicos de execução do plano, os projetos não são especificados quando da fase de elaboração do plano, sendo concebidos em outro nível de organização administrativa. Uma vez que requerem estudos específicos, serão elaborados pelos organismos executores. Estes sim, deverão

${ }^{7}$ O conceito de programa aqui utilizado é o definido por Carvalho (1978): "um componente do plano, ou seja, uma subdivisão que permita agrupar as decisões por áreas de ação semelhantes sob o mesmo título". 
ser especificados juntamente com a sua área geográfica de atuação e o tipo de participação prevista. (Carvalho, 1978). Conjuntos de projetos de setores ou regiões específicas determinam programas que, quando agregados, constituem os planos (Szmercsányi, 1979).

Tendo sido elaborado, o plano deve ser estudado várias vezes para que se possa determinar a coerência entre os objetivos, metas, infra-estrutura, recursos humanos $\mathrm{e}$ financeiros previstos nas suas diferentes unidades. $\mathrm{O}$ estudo de coerência permite verificar a compatibilização entre os programas e projetos. Estabelece-se assim, a relação entre os programas e projetos para que ajam efetivamente como elos condutores dinamizando o processo de desenvolvimento do planejamento (Carvalho, 1978).

Depois do estudo de coerência, o plano deve ser executado, colocado em prática, para que sua viabilidade seja testada e para que o processo de planejamento possa ter continuidade. Se ficar apenas no papel, o plano será apenas um documento político que abrange um conjunto de decisões tomadas pelo governo, que procura orientar as ações públicas e privadas na prática do desenvolvimento (Carvalho, 1978) mas não se constituirá em uma intervenção que busca alterar a realidade de um determinado setor. Nesse sentido, a própria organização administrativa responsável pela implantação do plano deverá estar dimensionada para levar adiante os processos necessários para a concretização de suas proposições.

Por fim, deve haver uma avaliação periódica dos resultados da execução dos planos e programas, a partir do qual serão feitos os reajustes necessários à boa execução do plano através do tempo (Ackoff, 1981; Szmercsányi, 1979; Tinbergen, 1975). A avaliação e revisão periódica é necessária para que se possa elaborar novos programas e projetos, a partir das novas informações e dados disponíveis. (Tinbergen, 1975). 
A longo prazo, a avaliação permite reformular o diagnóstico inicial, a política de desenvolvimento e do próprio plano, conduzindo, em alguns casos, à elaboração de um novo plano (Smercsányi, 1979).

Também é aconselhável que o plano seja periodicamente revisto, à medida que novos dados se tornem disponíveis e novas idéias surjam (Tinbergen, 1975). O processo de planejamento só assume uma forma concreta e definitiva quando se traduz em uma sucessão de planos através do tempo, cujo prazo mínimo e vigência está relacionado a determinados critérios tecnológicos e/ou financeiros.

Insucessos de um plano decorrem de imperfeições relacionadas ao processo de planejamento e/ou resistência por parte de pessoas e grupos envolvidos. O Plano não é um modelo ao qual a realidade deve amoldar-se, mas um instrumento de modificação da realidade. O planejamento, como processo, deve conseguir amoldar-se ao seu objeto a fim de poder alcançar os seus objetivos (Szmercsányi, 1979). 


\section{MATERIAL E MÉTODO}

\subsection{Considerações gerais}

Conforme mencionado na introdução, o objetivo desta dissertação é analisar o PDFS enquanto parte de um planejamento para o setor florestal, identificando e discutindo eventuais imperfeições nas etapas de um processo de planejamento e que possam induzir ao não cumprimento de seus objetivos e metas. Em outras palavras, o que se espera ao analisar o PDFS é saber se ele foi um resultado isolado, um Plano com um fim em si mesmo, ou se ele faz parte de um processo mais amplo de intervenção, de um planejamento para o setor florestal paulista.

Segundo Szmercsányi (1979), insucessos de um plano decorrem de imperfeições relacionadas ao processo de planejamento e/ou resistência por parte de pessoas e grupos envolvidos. Assim, ao avaliar a presença e o cumprimento de cada etapa do processo de planejamento no PDFS, é possível verificar as imperfeições relativas à condução deste processo, verificando se ele constitui um conjunto coerente de partes relacionadas entre si, necessário para produzir os resultados e objetivos da intervenção que se propõe a realizar. Também será conduzida uma análise da resistência por parte de grupos e pessoas envolvidas a que se refere Szmercsányi (1979).

Para proceder a estas análise, é essencial que se faça um estudo sobre planejamento, seus diferentes tipos e matrizes conceituais, além das etapas concernentes ao processo de planejamento. Este estudo encontra-se no Capítulo 
2, no qual definiu-se por utilizar como referencial, dentre as diversas matrizes conceituais existentes, a terceira matriz elaborada por Szmercsányi (1979) e o Planejamento Estratégico Situacional (PES) desenvolvido por Carlos Matus (Arroyo, 1996), pelos motivos expostos. Além disso, a identificação e a discussão de eventuais falhas do PDFS enquanto planejamento, serão feitas na seqüência das etapas do processo de planejamento apresentadas na matriz conceitual de Szmercsányi (1979), anteriormente descritas e enumeradas, também no Capítulo 2.

Finalmente, para averiguar se o PDFS foi um Plano com um fim em si mesmo, ou se ele faz parte de um processo de um planejamento para o setor florestal paulista, é preciso saber o que foi este Plano. Assim, neste capítulo será feita uma descrição do PDFS com base em publicação da Fundação Florestal (Fundação, 1993), buscando uma compreensão do Plano em seu todo, apresentando os aspectos principais de seu conteúdo, sem tomar uma posição quanto aos conceitos e propostas apresentados. Os elementos do Plano foram reordenados nessa apresentação para facilitar a sua comparação com as etapas de um processo de planejamento traçadas na revisão bibliográfica. Esta comparação será a base da análise do PDFS enquanto uma intervenção no setor florestal paulista, e será realizada no próximo capítulo.

\subsection{O Plano de Desenvolvimento Florestal Sustentável - PDFS}

Em outubro de 1993, a Secretaria de Estado do Meio Ambiente, do Governo do Estado de São Paulo, por intermédio da Fundação Florestal ${ }^{8}$, lançou o "Plano de Desenvolvimento Florestal Sustentável - PDFS" como uma estratégia de ação para o setor florestal em um horizonte de 25 anos. É um plano

${ }^{8}$ A Fundação para a Conservação e a Produção Florestal do Estado de São Paulo - Fundação Florestal - é uma fundação pública de direito privado vinculada à Secretaria do Meio Ambiente do Estado de São Paulo. 
de caráter indicativo, que procura ordenar as ações do Estado e orientar os rumos a serem trilhados pela iniciativa privada.

Sua implantação, realizada por meio de programas diferenciados, envolvem atividades de fomento ${ }^{9}$, de produção e distribuição de mudas e sementes florestais, visando a recuperação de mananciais e microbacias e criando alternativas de renda para produtores rurais. A meta a ser alcançada é o plantio de cerca de quatro milhões de hectares de florestas, entre espécies nativas e exóticas ${ }^{10}$.

O PDFS foi elaborado seguindo três diretrizes básicas extraídas a partir dos conceitos de desenvolvimento auto-sustentado da $\mathrm{ONU}^{11}$ e de conservação da IUCN12: a conservação, a produção auto-sustentada e a educação ambiental. Estas três diretrizes são destacadas no PDFS como parâmetros básicos a serem utilizados dentro de uma política ambiental, seguindo conceitos de conservação de recursos naturais com vistas ao "desenvolvimento integrado e autosustentado (...) favorecendo não apenas resultados econômicos concretos mas, sobretudo, adequação social e equilíbrio ecológico" (Fundação, 1993, p.2).

O conceito de conservação utilizado, em seu estrito senso, está relacionado, primordialmente, à manutenção de bancos genéticos primitivos do Estado. Sua importância para o Plano se dá enquanto fonte de pesquisas científicas direcionadas para o surgimento de alternativas de desenvolvimento de regiões preservadas, enquanto modelo de estudo dos processos de regeneração de florestas a serem utilizados para a recuperação de áreas degradadas e cumprindo um papel pedagógico.

${ }^{9} \mathrm{O}$ fomento no setor agronômico e florestal é uma modalidade de assistência técnica em cujas finalidades pode-se destacar: o fornecimento de insumos para a produção, a prestação de serviços básicos e a assistência propriamente dita. (Ver QUEDA \& SZMERCSÁNYI, 1976).

${ }^{10}$ Espécie nativa: aquela que suposta ou comprovadamente é originária da área geográfica em que atualmente ocorre. Espécie exótica: aquela presente em uma determinada área geográfica a qual não é originária, introduzida geralmente pelo homem (ACIESP, 1997).

${ }^{11}$ ONU: Organização das Nações Unidas.

${ }^{12}$ IUCN: União Internacional de Conservação da Natureza. 
A produção auto-sustentada, por sua vez, refere-se à produção "capaz de subsistir no tempo para atender à demanda das gerações futuras, mantendo o potencial produtivo (...) reduzindo as pressões sobre o remanescente de florestas nativas, especialmente no que se refere à demanda energética" (Fundação, 1993, p.9).

A aplicação da educação ambiental será direcionada para:

“conscientizar a população para seu papel de beneficiária final do processo de conservação (...) procurando gerar recursos humanos capazes de, a curto prazo, proporcionar uma gestão adequada das questões ambientais e uma racionalização progressiva das decisões relativas ao emprego das tecnologias e, ao longo prazo, introduzir processos produtivos poupadores de recursos naturais" (Fundação, 1993, p.10).

Estas três "linhas operacionais", como são chamadas no Plano, podem ser entendidas como três princípios gerais que se constituem um corpo geral, diretrizes amplas de uma política florestal para o qual o PDFS espera contribuir. Na verdade, como pode ser visto logo na primeira página do Plano, o PDFS é “produto de um trabalho desenvolvido durante vários anos, (...) é o eixo principal da política florestal a ser adotada pelo Estado de São Paulo e apresenta uma síntese das propostas que permeiam direta ou indiretamente o setor".

Os objetivos ambientais e sócio-econômicos propostos para a implantação do PDFS são abaixo enumerados:

1. Objetivos ambientais a serem alcançados com a implantação do PDFS

- frear o processo de degradação ambiental causada pela redução da cobertura florestal;

- reverter o processo de pré-desertificação de algumas regiões do Estado; 
- proteger e aumentar mananciais;

- iniciar um processo de regeneração da vegetação nativa, de modo a se atingir um equilíbrio ambiental duradouro, de acordo com índices preconizados internacionalmente;

- fixar parte do excesso de $\mathrm{CO}_{2}$ atmosférico na forma de fitomassa;

- desenvolver técnicas de produção florestal auto-sustentada e com a devida proteção do meio ambiente;

- desenvolver uma consciência ambiental na população e;

- estabelecer uma cooperação efetiva entre Estado, entidades científicas, empresas e demais organizações civis, para viabilizar a implantação dos programas previstos.

2. Objetivos sócio-econômicos a serem alcançados com a implantação do PDFS

- redução de custos em propriedades rurais, nos municípios e no Estado;

- aumento da arrecadação pública, diretamente, pelo aumento da produção e, indiretamente, pela maior utilização de insumos, serviços e mão-de-obra direta, além de um incremento geral à indústria e ao comércio;

- geração de novos empregos, visto que, em termos médios, cada 10 ha de florestas geram, para sua plantação, manutenção, exploração e utilização dos seus produtos nas indústrias do setor, 1 (um) emprego. Além disso, serão criadas novas oportunidades de investimento, como o estímulo à instalação de viveiros e criação de serviços ligados às atividades florestais. Em fases de implantação de maciços, cada 4 ha de florestas geram 1 (um) emprego direto.

Para alcançar tais resultados, a configuração do PDFS partiu de uma análise da situação do setor florestal do Estado, sem perder de vista 
procedimentos a serem adotados para a implementação de um desenvolvimento florestal sustentável.

Tendo considerado os fatores internacionais e nacionais dentro do horizonte de 25 anos previsto para o alcance do Plano, fez-se uma análise, em que se verificaram os problemas advindos da redução da cobertura vegetal, especialmente das florestas, e quais seriam as diretrizes gerais que balizariam o Plano e sua subseqüente programação. Em seguida, procedeu-se a um diagnóstico da situação atual da cobertura vegetal nativa e de reflorestamento. Também foi determinado o estoque de terras potencialmente apto às atividades florestais, sem concorrência com as explorações agrícolas e pecuárias.

Por fim, foi estimado o consumo atual de produtos florestais e a partir da análise das perspectivas mundiais e dos comportamentos previsíveis de variáveis macroeconômicas, sociais e ecológicas, estabelecido um provável crescimento desta demanda, para uso industrial, insumo energético e/ou outros usos.

Levando em consideração estes parâmetros e tendo considerado a situação da tecnologia atual e seu provável desenvolvimento, determinou-se, para o Estado de São Paulo, a dimensão atual do mercado, as necessidades de recuperação em termos de vegetação nativa e o que seria preciso fazer para atender a demanda atual e futura de madeira para fins energéticos e matériaprima. Também foram consideradas as políticas oficiais e mesmo empresariais e as estruturas setoriais públicas, privadas e associativas que atuam no setor. $O$ produto final dessa análise configurou o PDFS em suas linhas gerais e na programação subseqüente, prevendo-se componentes de controle, realimentação e correção de rumos ao longo do tempo (ver Anexo 1).

O diagnóstico da situação atual da cobertura vegetal nativa e de reflorestamento mostra que dos 24 milhões de hectares do Estado, 3,1 milhões de hectares estão ocupados com formações florestais e vegetação nativa 
localizadas em áreas que não concorrem com explorações agrícolas e pecuárias ${ }^{13}$. Outros 0,7 milhões de hectares estão sendo utilizados para reflorestamentos, seja com espécies de Eucaliptus spp. ou de Pinus spp. Assim, o Estado de São Paulo tem 3,8 milhões de hectares ocupados por formações e vegetação nativas e reflorestamentos com espécies exóticas com fins de produção.

Para determinar a área a ser recuperada, foi utilizado o valor de $30 \%$ do território paulista com cobertura florestal, considerado no PDFS um índice internacionalmente reconhecido de equilíbrio para a cobertura florestal de um determinado território. Assim, o Estado de São Paulo deve ter 7,2 milhões de hectares com cobertura florestal. Tendo levado em conta a existência de 3,8 milhões cobertos com florestas, o PDFS se coloca a meta de plantar entre 20 e 25 anos, no mínimo 2,4 milhões de hectares e no máximo 3,7 milhões de hectares, sendo 1,6 milhões de hectares com espécies nativas e 0,8 a 2,1 milhões de hectares com espécies exóticas com fins de produção para abastecer o mercado de madeira e de outras matérias-primas.

O intervalo de tempo para a execução do Plano - entre 20 e 25 anos - foi estipulado levando-se em consideração o período de rotação de uma floresta, permitindo a manutenção de um potencial produtivo auto-sustentado. Também é um período de tempo considerado pelos planejadores do PDFS como provável para o surgimento de algum tipo de mudança tecnológica nas atividades silviculturais. Além disso, "imposições de ordem legal, como previstas na Lei Agrícola (Lei Federal $n^{\circ}$ 8.171, de 17/01/91) e na proposta do Código Ambiental do Estado (Lei Florestal $n^{\circ} 4.771$, de 15/10/69), prescrevem uma recuperação da reserva legal num prazo entre 20 e 30 anos" (Fundação, 1993, p.27).

${ }^{13}$ Classes VII e VIII de capacidade de uso do solo. As classes de capacidade de uso do solo são uma classificação do uso da terra em função da declividade, erosão, uso atual e natureza (diferenciação) do solo e indica o grau de intensidade de cultivo que pode ser aplicado em um terreno sem que o solo sofra diminuição de sua produtividade (Bertoni \& Lombardi Neto, 1990). 
Dessa forma, traçou-se a meta do Plano de Desenvolvimento Florestal do Estado de São Paulo: o plantio de 1,6 milhões de hectares de florestas nativas e entre 0,8 milhões e 2,1 milhões de hectares de florestas exóticas, em cerca de 25 anos.

Tendo definido as metas e os objetivos, o PDFS foi estruturado em quatro Programas, a saber: Programa de Zoneamento Sócio-Econômico e Ecológico; Programa de Produção e Distribuição de Sementes e Mudas Florestais; Programa de Formação de Florestas de Conservação e de Produção; e o Programa de Florestas Regionais. Cada qual apresenta objetivos próprios.

O Programa de Zoneamento Sócio-Econômico e Ecológico é considerado um programa básico que deverá gerar informações técnicas, proporcionando uma ocupação florestal racional do território paulista. Ele prevê as seguintes atividades:

- levantar e divulgar o zoneamento das espécies de essências nativas e exóticas adaptadas às diversas situações de solo e de clima do Estado de São Paulo, informando ainda a tecnologia recomendada para o plantio, condução e aproveitamento;

- indicar as áreas prioritárias para reflorestamento, considerando classes de capacidade de uso do solo, balanço hídrico, presença de áreas ecologicamente frágeis, áreas de proteção de mananciais, proteção de hidroelétricas;

- elaborar estudos de mercado do setor madeireiro para levantar a produção e o consumo por região e finalidade, fornecendo indicações de déficit e superávit de produto, orientando o plantio e contribuindo, a médio prazo, para a definição da futura matriz energética do Estado;

- manter atualizado o Inventário Florestal do Estado. 
As atividades previstas para este Programa, que contempla atividades como estudo de áreas prioritárias para o reflorestamento e de mercado do setor madeireiro, permite-nos perceber sua importância enquanto geradora de pesquisa e informações básicas necessárias para os outros três Programas do PDFS.

O Programa de Florestas Regionais foi concebido como um programa de fomento à criação de unidades de conservação regionais. Delimitadas em áreas de vocação florestal para proteção e áreas de $\mathrm{APAs}^{14}$, as Florestas Regionais teriam uma utilização direcionada ao turismo ecológico, educação ambiental e programas de uso alternativo.

O Programa de Florestas de Conservação e de Produção apresenta como objetivos a recuperação das áreas degradadas do Estado, com essências nativas, e o plantio e replantio de florestas de produção. As florestas de produção serão implantadas pelas empresas do setor florestal - as indústrias de celulose e papel e do setor madeireiro - em áreas próprias e fomentadas em áreas de pequenos e médios agricultores pelas Associações de Reposição Florestal15. Caberá ao Estado as ações voltadas para o plantio de essências nativas, viabilizando a implantação das Florestas de Conservação.

Uma destas ações é o próprio Programa de Produção e Distribuição de Sementes e Mudas Florestais, cujo objetivo é "possibilitar a produção e a distribuição de sementes e mudas de essências nativas e exóticas, em

${ }^{14}$ Áreas de Proteção Ambiental: "unidades de conservação destinadas a proteger e conservar a qualidade ambiental e os sistemas naturais existentes. Visam a melhorar a qualidade de vida da população local e proteger os ecossistemas naturais; pressupõem o zoneamento econômico-ecológico e uma Zona de Vida Silvestre; são permitidas as atividades agrícolas ou agropecuárias; são proibidas as atividades de terraplanagem, mineração, drenagem e escavações que causem danos ao meio ambiente."(São Paulo, 1998)

${ }^{15}$ As Associações de Reposição Florestal são associações sem fins lucrativos credenciadas pelo Instituto Brasileiro do Meio Ambiente - IBAMA - e o Departamento Estadual de Proteção aos Recursos Naturais - DEPRN - para proceder ao fomento florestal pelo recolhimento da Taxa da Reposição Florestal Obrigatória no Estado de São Paulo 
quantidade e qualidade suficientes para garantir os plantios previstos" (Fundação, 1993, p.32).

Tendo seus objetivos, metas e programas definidos, o PDFS estabeleceu a sua base de atuação em oito regiōes, referentes a oito bacias hidrográficas, apoiando-se na divisão oficial do Departamento de Águas e Energia Elétrica e nas categorias de aptidão agrícola. São elas, as bacias hidrográficas do Alto Tietê; Médio e Baixo Tietê; Rios do Peixe e Aguapeí; Rio Paranapanema; Rio Ribeira e Litoral; Rio Paraíba; Rios Pardo e Mogi Guaçu e; Rios Turvo e São José dos Dourados.

Mesmo norteando-se por uma coordenação central, para cada uma destas oito bacias hidrográficas, o PDFS considera fundamental a discussão com organizações da sociedade civil que estarão envolvidas na realização do Plano. O envolvimento do poder local também é considerado como fator importante: “a formação de consórcios de prefeituras (...) parece ser a melhor opção formal de participação do Poder local no PDFS"(Fundação, 1993, p.43). É a partir do envolvimento possível de participantes das organizações da sociedade civil e das prefeituras que se elaborou o esquema de avaliação do Plano' ${ }^{16}$.

Com relação aos recursos necessários para a execução do Plano, as duas principais fontes de financiamento previstos são o Estado e a iniciativa privada. As empresas do setor florestal produzirão e distribuirão as sementes de espécies exóticas para os programas de fomento de reflorestamento que visam a produção de madeira para o abastecimento energético e de matéria-prima.

Com o Estado ficará o ônus da produção e de distribuição de sementes de essências florestais nativas para os programas na área de conservação e preservação. A participação majoritária dos recursos virá do Estado, que também contará com convênios com instituições públicas, universidades e outras organizações. Os planejadores do PDFS prevêem a possibilidade de 
recursos provenientes da renegociação da dívida externa brasileira, de organizações internacionais não governamentais e organismos oficiais internacionais.

Os recursos financeiros necessários para a implantação e execução dos objetivos e metas do PDFS são da ordem de 4,5 bilhões de dólares em 25 anos. Uma vez que nestes valores a participação por tipo de florestas (exóticas para reflorestamento e nativas para proteção e conservação) é praticamente meio a meio, cada setor, privado e público, deverá obter e/ou movimentar 2,25 bilhões de dólares em 25 anos, ou seja, em média, 90 milhões de dólares por ano.

${ }^{16}$ ver pg. 44 do PDFS (Fundação, 1993). 


\section{RESULTADOS E DISCUSSÃO}

Retomando a revisão bibliográfica apresentada no início dessa dissertação, veremos que o processo de planejamento caracteriza-se como um conjunto de etapas pelo qual irá se realizar uma determinada intervenção. Portanto, enquanto processo, ele obedece a relações de interdependência que o identifica como um conjunto de partes relacionadas entre si. Um conjunto coerente, que deverá produzir resultados finais ou resultar em objetivos que facilitem o aumento da eficácia da intervenção.

Ao avaliar a presença e o cumprimento de cada etapa do processo de planejamento no PDFS, é possível verificar as imperfeições relativas à condução deste processo, verificando se ele constitui um conjunto coerente de partes relacionadas entre si, necessário para produzir os resultados e objetivos da intervenção que se propõe a realizar.

As análises do PDFS serão feitas em três tópicos. No primeiro, serão investigadas as etapas do processo de planejamento anteriores à formulação do PDFS. No segundo, serão analisadas as etapas concernentes à elaboração do Plano e que resultou na sua concepção. No terceiro e último tópico, analisar-se-á o processo de planejamento após a elaboração do Plano, ou seja, as etapas posteriores à sua elaboração.

Em alguns casos, recorrer-se-á à revisão bibliográfica e à descrição do PDFS para situar a discussão e possibilitar uma melhor compreensão da análise em questão. 


\subsection{As etapas do processo de planejamento anteriores à elaboração do PDFS}

Duas são as etapas de um processo de planejamento anteriores à elaboração de um plano: o diagnóstico e a definição das políticas para o setor que se pretende alterar.

\subsubsection{O diagnóstico do setor a ser alterado}

O Plano apresenta não só um diagnóstico, como também um prognóstico da evolução do setor florestal paulista para os próximos 20-25 anos. Amparando-se em levantamentos oficiais da cobertura florestal do Estado, torna-se evidente a evolução acelerada da supressão da cobertura vegetal florestal, prevendo-se a manutenção ou o agravamento dessa tendência para as décadas subseqüentes caso medidas não sejam tomadas. Os dados apresentados mostram que a cobertura vegetal original das matas no Estado de São Paulo correspondia a cerca de $80 \%$ de seu território. Já em 1907 , as matas cobriam o equivalente a $58 \%$ do território, sendo que, em 1991, apenas $12,8 \%$ do território apresentava matas nativas.

Acompanhando tal diagnóstico, são descritas as conseqüências que já se fazem sentir e que certamente serão intensificadas pela crescente redução da cobertura florestal: erosão e empobrecimento da fertilidade do solo, assoreamento de corpos d'água, perda da biodiversidade, reduções de mananciais de água potável, dentre outros.

Também é apresentado o diagnóstico da cobertura do território ocupado por reflorestamentos com fins de produção, cerca de 730.000 hectares ( $3 \%$ do território). Segundo estimativas apresentadas no Plano, o Estado apresentava um déficit de 510.000 hectares de reflorestamentos. $O$ prognóstico de sua evolução, a partir da estimativa do consumo de produtos florestais e provável crescimento do setor, projeta, para um horizonte de 20-25 anos, um parque 
florestal produtivo que deverá ter de 1.500 .000 a 2.800 .000 hectares com essências exóticas.

Finalmente, são apresentados os estoques de terras potencialmente aptos às atividades florestais sem concorrer com as atividades agropecuárias, obtendo-se de $25 \%$ a $30 \%$ do território com aptidão florestal, seja para reflorestamento, seja para florestas de proteção e conservação.

As informações que são apresentadas no diagnóstico podem ser assim resumidas:

- problemas advindos da redução da cobertura florestal;

- diagnóstico da situação atual da cobertura florestal do Estado;

- determinação dos estoques de terras potencialmente aptos às atividades florestais sem concorrer com as atividades agropecuárias;

- estimativa do consumo de produtos florestais e seu provável crescimento;

- situação atual da tecnologia silvicultural e seu desenvolvimento ${ }^{17}$.

Pode-se concluir que o diagnóstico apresenta variáveis relevantes para a compreensão da situação atual da cobertura florestal no Estado por meio de pesquisas e levantamentos, além de informações sobre a sua evolução histórica e as tendências que possam resultar num prognóstico acerca da evolução futura do setor, sem levar em conta possíveis efeitos da intervenção que se pretende executar. Demonstra-se que há a necessidade de intervenção, no sentido de aumentar a cobertura florestal com fins de proteção e produção, dando elementos que indicam que uma intervenção é aconselhável e que as aptidões do território paulista abrem esta possibilidade.

No entanto, pode-se fazer uma ressalva quanto às informações apresentadas. Não há diagnóstico neutro, ou seja, toda pesquisa, por maior que seja seu rigor científico, está impregnada com a subjetividade do pesquisador. $O$

${ }^{17}$ Não há um aprofundamento no Plano sobre o que significa o desenvolvimento da tecnologia silvicultural e suas implicações para o PDFS. 
produto resultante, por conseqüência, também estará impregnado por tal subjetividade.

Não está sendo questionado o rigor científico ou a profundidade com que tais informações apresentadas foram geradas, mesmo que haja subjetividade nestes dados. Contudo, percebe-se, nas informações do diagnóstico e na maneira como foram apresentadas, indicativos claros de uma solução para o problema da baixa cobertura florestal no Estado.

Isto pode ser detectado se observarmos os dados fornecidos para se determinar a quantidade de área por recuperar. É estabelecido o valor de $30 \%$ do território paulista a ser recuperado com cobertura florestal, por ser um índice internacionalmente reconhecido de equilíbrio para a cobertura florestal de um determinado território. Em determinado momento, são apresentados os estoques de terras potencialmente aptos às atividades florestais, sem concorrer com as atividades agropecuárias, obtendo-se de 25 a $30 \%$ do território com aptidão florestal, seja para reflorestamento, seja para florestas de proteção e conservação. Tais dados são apresentados de maneira a consolidar a proposta de recuperar $30 \%$ do território paulista, seja com florestas nativas para proteção como florestas exóticas para produção.

O diagnóstico é uma pesquisa rigorosa e com profundidade científica e, mesmo que no produto desta pesquisa esteja incutida a subjetividade do pesquisador, ela não deve dar origem diretamente a um plano. Quem deve processar as informações do diagnóstico são os indivíduos, os atores sociais que serão envolvidos na execução do planejamento. É a partir de suas diferentes percepções e perspectivas da realidade, juntamente com as informações do diagnóstico, que serão definidos os objetivos e as metas do Plano. Ou seja, os diversos atores sociais são os responsáveis pela formulação da política e pela escolha dos objetivos. 
Se a leitura dos planejadores, com relação à situação florestal do Estado e às medidas concebidas para solucionar tais problemas, não é compartilhada pelos proprietários rurais, o PDFS enfrentará muitas resistências para ser implementado. Esta discussão será aprofundada mais à frente.

O diagnóstico em um plano deve tão somente reconhecer as variáveis relevantes para a compreensão da estrutura e do funcionamento do setor a ser alterado e, por meio de pesquisas e levantamentos, obter indicadores explicativos da situação atual. Nunca, contudo, conduzir a propostas. O diagnóstico não deve dar origem, diretamente, a nenhum Plano.

\subsubsection{A politica de desenvolvimento para o complexo que se deseja alterar}

Como nenhum plano real é formulado apenas com base em diagnósticos, é necessária a formulação de uma política de desenvolvimento para o setor cuja evolução futura se pretende planejar. As diretrizes políticas explicitadas para o setor florestal, sobre as quais se configurou o PDFS, podem ser observadas abaixo:

- desenvolvimento integrado e auto-sustentado;

- princípios da União Internacional de Conservação da Natureza: conservação, produção auto-sustentada e educação ambiental;

- busca de resultados econômicos, adequação social e equilíbrio ecológico;

- índice mínimo de 25-30\% do território com cobertura florestal;

Não cabe, nesta dissertação, avaliar se as diretrizes políticas utilizadas para a elaboração do PDFS são ou não adequadas e/ou pertinentes para o Estado de São Paulo. Para analisar o Plano, enquanto instrumento do processo de planejamento, basta identificar se as diretrizes políticas que nortearam a sua configuração estão explicitadas.

Uma vez apresentadas as informações dos diagnósticos e prognósticos para o setor florestal e as diretrizes políticas norteadoras do Plano, pode-se 
concluir que os planejadores que conceberam o PDFS cumpriram as etapas básicas anteriores à sua elaboração.

\subsection{As etapas do processo de planejamento concernentes à elaboração do PDFS}

\subsubsection{A definição dos objetivos do PDFS}

Segundo Szmercsányi (1979), a elaboração de um plano, propriamente dito, inicia-se ao confrontar as informações obtidas a partir do diagnóstico com os princípios definidos na política de desenvolvimento, obtendo-se um conjunto de objetivos para a evolução futura do setor que se pretende submeter ao planejamento.

Os objetivos - ambientais e sócio-econômicos - a serem alcançados com a implementação do plano de que são orientadores para o setor florestal são elencados abaixo:

A) Objetivos ambientais a serem alcançados com a implantação do PDFS

- frear o processo de degradação ambiental causada pela redução da cobertura florestal;

- reverter o processo de pré-desertificação de algumas regiões do Estado;

- proteger e aumentar mananciais;

- iniciar um processo de regeneração da vegetação nativa, de modo a se atingir um equilíbrio ambiental duradouro, de acordo com índices preconizados internacionalmente;

- fixar parte do excesso de $\mathrm{CO}_{2}$ atmosférico na forma de fitomassa;

- desenvolver técnicas de produção florestal auto-sustentada e com a devida proteção do meio ambiente;

- desenvolver uma consciência ambiental na população; e

- estabelecer uma cooperação efetiva entre Estado, entidades científicas, empresas e demais organizações civis, para viabilizar a implantação dos programas previstos. 
B) Objetivos sócio-econômicos a serem alcançados com a implantação do PDFS

- redução de custos em propriedades rurais nos municípios e no Estado;

- aumento da arrecadação pública, direta e indiretamente; e

- geração de novos empregos.

\subsubsection{Os objetivos do Plano e a participação da população na sua definição}

Antes de serem transformados em metas, os objetivos definidos pelos planejadores deverão ser colocados para apreciação e discussão aos órgãos encarregados pela execução do plano, mas principalmente às populações, grupos ou indivíduos que, direta ou indiretamente, estão ou estarão envolvidos no processo de planejamento, ou sofrerão os efeitos da intervenção nele programada (Szmercsányi, 1979).

Depreende-se, da leitura do Plano como um todo, que esta etapa não ocorreu, uma vez que somente depois de definidas as metas, objetivos e programas, faz-se menção à participação de outros atores, ou seja, é apenas na execução que a sociedade é chamada a participar. Alguns elementos interessantes podem ser extraídos no que diz respeito ao Plano e à participação da sociedade em sua elaboração.

O primeiro questionamento aqui levantado diz respeito à pressuposição que aqueles que estarão envolvidos na realização do Plano (grupos, indivíduos, organizações) serão "apresentados" ao PDFS depois de estabelecidos os objetivos e as metas. Segundo Carvalho (1978), esta diferenciação entre quem planeja e quem executa o plano cria uma necessidade de comunicação entre planejadores e executores. Quando ocorre esta dicotomia os, "componentes de informação em planos, programas e projetos" (Carvalho, 1978, p.32), acontece pela necessidade de divulgar os objetivos do plano. Informar, no sentido de motivar, induzir ou persuadir os indivíduos que deverão ser mobilizados para a execução do plano, da "oportunidade" e "importância" do trabalho a ser 
realizado (Carvalho, 1978). Estabelece-se, portanto, o anti-diálogo, consolidando-se a não-participação da sociedade em uma intervenção que the diz respeito diretamente. "Manipulam-se as massas populares oferecendo-lhes elementos para pensar, não criando os canais para a participação na decisão" (Carvalho, 1978, p.32)

O segundo questionamento, anterior ainda ao acima mencionado, diz respeito à concepção do planejamento adotado que, segundo Matus ${ }^{18}$, o caracteriza como um planejamento de caráter Normativo ou Tradicional, no qual os planejadores assumem que o setor que querem intervir é estático, predizível com total segurança. Ou seja, assume-se que tudo o que estiver fora do controle do ator social que planeja é predizível. Mesmo objetivando-se um planejamento que adentra no campo da político-social, "essencialmente complexo, variável, incerto e nebuloso" (Huertas, 1996, p.52).

Para o Planejamento Tradicional, os outros atores sociais envolvidos na execução do plano são incapazes de tomar decisões ou ter objetivos diferentes, porque considera-se que estes atores sociais - sindicatos, consumidores, empresários, associações e outros - apresentam condutas predizíveis, pois seguem leis e normas (Huertas, 1996). Assim, o único ator social que planeja é o Governo e seu plano deverá ser executado pelos outros atores sociais porque estes seguem leis e normas.

Quando se analisa o PDFS, percebe-se que este pressuposto baliza a elaboração do Plano, caracterizando-o como um Planejamento Tradicional, configurado por um único ator social, o Estado, que define os objetivos e já determina as metas a serem alcançadas, no caso, o plantio de 1,6 milhões de hectares com florestas nativas para proteção e conservação e de 2,1 milhões de hectares com florestas para produção de madeira em um tempo estimado de 25

\footnotetext{
${ }^{18}$ ver (Huertas, 1996), p.50-65.
} 
anos. Para o cumprimento das metas, serão necessárias 300 milhões de mudas, por ano, entre espécies nativas e exóticas, para o plantio de 148 mil hectares.

Quando se assume, no PDFS, metas extremamente ousadas, está-se admitindo que todos os outros atores sociais envolvidos, no caso os proprietários rurais e quem os representa, estão concordando em recuperar as suas áreas de preservação permanente e reserva legal. Ou seja, pressupõe-se que suas ações são predizíveis. E se admite isso em função de leis já estabelecidas: "Além disso, imposições de ordem legal, como previstas na Lei Agrícola (Lei Federal $n^{\circ}$ 8.171, de 17/01/91) e na proposta do Código Ambiental do Estado (Lei Florestal $n^{\circ} 4.771$, de 15/10/69), prescrevem uma recuperação da reserva legal num prazo entre 20 e 30 anos" (Fundação, 1993, p.27).

A formulação de leis não é o suficiente para criar demandas para a recuperação de áreas de preservação permanente e reserva legal. Prova disso está no resultado da aplicação da Lei Estadual paulista de $\mathrm{n}^{\circ}$ 9.98919, regulamentada em 1998. Oito meses após sua aprovação, que obriga o proprietário rural a recuperar as suas áreas de preservação permanente, nenhum projeto de recomposição foi apresentado ao Departamento Estadual de Proteção de Recursos Naturais (DEPRN), dentro do prazo de 180 dias exigido pela Lei ${ }^{20}$.

Por que isso ocorre? Porque a demanda criada por estas leis e planos, não vão de encontro as demandas do público a que se destina e, portanto, não são valorizadas por eles (Huertas, 1996). Se os objetivos e metas propostos para o PDFS não corresponderem às aspirações e às reais necessidades daqueles que estarão envolvidos na sua execução, tal plano não encontrará respaldo e sua implementação sofrerá resistências, tendendo, até, a tornar-se inviável

${ }^{19}$ O Estado de São Paulo foi o primeiro a obrigar o proprietário rural a recuperar as suas áreas de preservação permanente (APP).

${ }^{20}$ Ver "Paulistas descumprem...." (s/d). 
(Szmercsányi, 1979). Nesse sentido, a população desempenha um papel de autora, executora e beneficiária do processo de planejamento. Mesmo aqueles que não sejam agentes executores diretos dos objetivos dos planos, serão atingidos pelas medidas de intervenção em quaisquer que sejam os niveis e camadas sociais (Carvalho, 1978).

Em nenhum momento há menção no PDFS sobre a opinião dos proprietários rurais no tocante à recuperação das áreas de preservação permanente em suas propriedades. Há uma ausência de preocupação nesse sentido, fruto da adoção de um planejamento de caráter tradicional ou normativo.

O planejamento concebido a partir desta visão normativa ou tradicional resulta em planos de ação tecnicamente corretos, mas politicamente inadequados e de difícil implantação, porque contempla o ponto de vista apenas de quem planeja e não incorpora a visão dos outros atores sociais que serão envolvidos na execução do planejamento. Um planejamento tradicional ignora a diversidade dos atores sociais envolvidos: proprietários capitalizados e descapitalizados; tecnificados e sem tecnificação; latifúndios e micro propriedades; chácaras e fazendas. Parte-se do princípio que há apenas uma leitura dos problemas e de como solucioná-los, e não do princípio que não existe uma leitura única e correta da realidade, mas que diferentes atores têm visões diferentes da realidade a partir da sua perspectiva ou situação. Há a ausência de estratégias múltiplas para captar e trabalhar as leituras dos diferentes proprietários, que propiciariam ao Plano uma maior flexibilidade de ação.

Os planejadores do PDFS partiram do princípio que a sua leitura da situação florestal do Estado e que as medidas concebidas para solucionar tais problemas são compartilhadas por todos os proprietários rurais paulistas. Ou, no mínimo, se não era compartilhada, que eles teriam que obedecer às leis. Mas se isso é verdade, como explicar que, ao longo dos anos, os índices da cobertura 
florestal nativa vêm diminuindo paulatinamente, mesmo diante de sua importância para a sociedade e mesmo existindo leis restritivas de corte e de obrigatoriedade de plantio ${ }^{21}$ que visam estancar este processo?

Os produtores que não compartilham destas leituras, isto é, da necessidade de recuperar as áreas de preservação permanente e reserva legal de suas propriedades, colocam resistência a este tipo de ação, o que comprometerá os objetivos e metas do PDFS.

Buscou-se obter informações junto à Fundação Florestal, relatórios de avaliação do cumprimento das metas e objetivos, para obter dados que consubstanciassem estas afirmações. Mas estas informações não puderam ser obtidas junto à Fundação Florestal, pela falta de dados, fruto de um processo sistemático de avaliação do Plano ${ }^{22}$. Apesar disso, em um relatório de estruturação da gerência de desenvolvimento florestal, ligada à diretoria de assistência técnica da Fundação Florestal, há uma menção que remete à resistência por parte dos produtores, expressa numa falta de demanda por mudas. Pode-se ler: "(...), o PDFS carecia de um projeto executivo de implantação, apresentando pouca eficácia pelas considerações expostas a seguir: (...). - Falta de um diagnóstico sobre a demanda local/regional por mudas: grande parte dos $\operatorname{contratos}^{23}$ foram firmados sem uma definição clara da demanda, resultando perdas das mudas no viveiro"(Fundação, 1996, p.2). Ou ainda: "- Aspectos de Extensão/Educação Ambiental: procurou-se trabalhar as dificuldades ${ }^{24}$ de implantação de florestas nas propriedades rurais" (Fundação, 1996, p.3).

${ }^{21}$ Por exemplo: Lei Federal n 4.771, de 15/09/1965 (Código Florestal); Lei Federal $n^{\circ} 8.171$, de 17/01/91(Lei Agrícola); Lei Estadual n ${ }^{\circ} 9.989$.

${ }^{22} \mathrm{O}$ problema da ausência de dados remete a uma ineficiência na avaliação do processo de planejamento. Isso será discutido a diante.

${ }^{23}$ Refere-se a contratos de parcerias para a produção e fomento de mudas.

${ }^{24}$ Não há um aprofundamento no relatório sobre quais seriam estas dificuldades. 
Assim, mesmo que não se obtenham dados do cumprimento das metas e objetivos do PDFS, esta resistência por parte dos executores do Plano foi identificada, sendo apresentada como um fator responsável pela pouca eficácia do PDFS. Esta resistência a planos e/ou programas de recuperação de áreas de preservação permanente e de reserva legal, foi identificada, inclusive, em programas semelhantes em outros Estados, como Minas Gerais e Bahia (Mueller, 1998). Mesmo em São Paulo, esta resistência já havia sido identificada pela CESP, em 1994, que enfrentava dificuldades para reflorestar as matas ciliares de propriedades rurais nas margens de seus reservatórios (CESP, 1994).

No entanto, apesar de identificarem estas resistências, tanto a CESP, quanto as experiências na Bahia e em Minas Gerais, se referem a ela como "falta de conscientização" por parte do proprietário rural da necessidade e dos benefícios de recuperar as áreas degradadas, ciliares e de preservação permanente, para quem há a necessidade de se empregar a "exortação", a “persuasão" e o "convencimento".

Todos estes programas, incluso o PDFS, não levam em consideração a possibilidade do proprietário rural ter uma leitura diferente da situação da baixa cobertura florestal, a partir da sua aspiração, condição e experiência de vida. Cada produtor avalia a situação que lhe é apresentada de modo particular e atua segundo sua própria interpretação da realidade (Huertas, 1996). Isso traz à discussão os diversos conhecimentos provenientes dos atores sociais, que apresentam leituras distintas a partir de sua situação, perspectiva ou ótica (Arroyo, 1996).

Saber trabalhar com os diversos atores sociais com as mais variadas leituras e intenções de ações demanda uma construção coletiva das decisões na diferença (Arroyo, 1996; Huertas, 1996). Ao planejador, portanto, cabe a função de catalisar o processo, trazendo à sociedade as informações para a definição de 
seus interesses, o conhecimento de suas necessidades e a disponibilidade dos meios de organização para lutar por seus objetivos.

O conflito existente na diversidade de opiniões deverá ser trabalhado visando a construção de objetivos que orientem o planejamento. Mais do que isso, o conflito estimula o debate entre os diversos atores sociais e torna o planejamento um recurso de fortalecimento político, estimulando a discussão, as decisões e as ações a serem tomadas ${ }^{25}$.

Se levarmos em consideração que os atores sociais envolvidos na execução do PDFS - os proprietários rurais - têm diferentes leituras sobre a situação da cobertura florestal nativa no Estado, e agem em função desta leitura, seria necessário um trabalho de longo prazo, trazendo informações necessárias para a definição de seus interesses e construindo, no conflito, os objetivos que farão parte do Plano e orientarão o planejamento. Dessa forma, haveria maior chance de os proprietários assumirem a sua parcela de responsabilidade nas decisões e objetivos, visto que eles teriam ajudado a construí-los, desempenhando um papel de autor, executor e beneficiário do processo de planejamento.

\subsubsection{A definição das metas do PDFS}

Somente após a discussão e uma aceitação mínima dos objetivos do plano é que são estabelecidas as metas, que devem ser definidas com relação aos seus aspectos quantitativos e qualitativos, prazos de realização e viabilidade política (Carvalho, 1978).

${ }^{25}$ Trabalhar o conflito que surge das diferentes leituras dos atores sociais, visando a construção de objetivos que orientem o planejamento, é tema do Planejamento Estratégico Situacional (PES), modalidade de planejamento desenvolvido pelo chileno Carlos Matus (Ver Huertas, 1996). 


\subsubsection{Aspectos qualitativos e quantitativos}

No PDFS, as metas foram definidas a partir dos objetivos traçados pela leitura que os planejadores tiveram da situação da cobertura florestal e de como eles entendiam que os problemas correlatos deveriam ser solucionados. Foram contemplados aspectos quantitativos e qualitativos. Entretanto, estes foram estabelecidos sem levar em consideração que os atores sociais envolvidos na execução do PDFS, os proprietários rurais, têm diferentes leituras sobre a situação da cobertura florestal e sobre a necessidade de recuperar as áreas de preservação permanente e reserva legal. Ou seja, sem considerar uma possível resistência pelos implementadores do Plano, o que compromete a consecução de suas metas.

\subsubsection{Os prazos de realização e a viabilidade política}

Com relação ao espaço de tempo previsto para a consecução de tais metas, o PDFS é um plano de longo prazo, quando a tendência seria a elaboração de um plano de curto prazo, de um ou dois anos, ou de médio prazo, que varia de cinco a sete anos (Carvalho, 1978). A partir de planos de curto e médio prazo, é possível providenciar possíveis reformas na estrutura administrativa visando sua adequação para a implantação de procedimentos de decisão e controle mais aprimorados (Carvalho, 1978).

Além disso, deve-se levar em conta que um plano é elaborado de acordo com o conjunto de fatores político-econômicos do momento. Ou seja, quando de sua elaboração, o plano tem condições de implantação devido ao apoio político daqueles que estão à frente do poder executivo, e até mesmo, do poder legislativo. No entanto, nada garante que a política adotada para o setor não será alterada quando houver a mudança de governo. E é exatamente isso o que se observa: muda-se o governo, alteram-se as políticas públicas. 
Este foi um fator negligenciado quando se estabeleceu o prazo de execução do PDFS. O Governo do Estado de São Paulo muda a cada quatro anos. Muda, portanto, a política do governo a cada quatro anos. Como então, definir metas para 25 anos? Quando foi lançado, em 1993, o PDFS contava com o apoio do então Governo Estadual para estabelecer a política para o setor. Em 1995, com a entrada de um outro Governador, mudaram-se as políticas para o Estado, que implantou, por exemplo, uma política de corte de investimentos, comprometendo a execução das metas do PDFS'26. Perdeu-se a viabilidade política para a implantação do Plano.

\subsubsection{A definição dos Programas do PDFS}

A escolha dos instrumentos mais adequados para a execução do Plano deve ser definida em função das metas estabelecidas. É nesse momento que se passa à definição e à elaboração dos programas que permitirão uma visão de conjunto do elenco de decisões que permitam uma intervenção coordenada e supostamente apoiada em critérios técnicos (Carvalho, 1978).

Tais programas foram definidos quando da elaboração do PDFS. São eles:

- Programa de Zoneamento Sócio-Econômico e Ecológico

- Programa de Produção e Distribuição de Sementes e Mudas Florestais;

- Programa de Formação de Florestas de Conservação e de Produção;

- Programa de Florestas Regionais.

Tendo seus objetivos, metas e programas definidos, o PDFS estabeleceu a sua base de atuação em oito regiōes, referentes a oito bacias hidrográficas, apoiando-se na divisào oficial do Departamento de Águas e Energia Elétrica e nas categorias de aptidão agrícola.

\footnotetext{
${ }^{26}$ Este ponto será aprofundado adiante.
} 
Como parte integrante de um plano e dentro do contexto do planejamento, o programa seria o resultado final da fase de tomada de decisões, tendo em vista o melhor uso dos recursos disponíveis para a consecução dos objetivos da intervenção, traçados durante o desenvolvimento das fases anteriores dentro do processo de planificação. Cada programa deverá ter seu conteúdo e objetivos diversos, detalhados e quantificados em termos físicos e financeiros (Szmercsányi, 1979).

Assim, em um programa, devem constar as metas físicas, especificando prazos e localização, além do estabelecimento dos recursos e organismos executores. Isto para cada setor ou região em que os programas serão executados. Deve incluir, também, estudos de coerência entre as metas e os recursos disponíveis (Carvalho, 1978).

\subsubsection{A especificação das metas dos Programas}

Um detalhamento por programa não é apresentado no PDFS. Apesar de todos os quatro Programas estabelecidos terem seus objetivos bem delineados, apenas os Programas de produção e distribuição de sementes florestais e o Programa de formação de florestas de conservação e de produção apresentam metas claras. A presença das metas nos programas são importantes porque permitem avaliar os objetivos estabelecidos, pelo próprio cumprimento destas metas. Isto fica claro quando entendemos que um objetivo é o resultado que se espera alcançar pelo desenvolvimento de uma atividade, sendo que a meta é a quantificação deste objetivo a ser alcançado num prazo definido (Carvalho, 1978). Portanto, um programa não pode prescindir de metas claras, pois elas são informações essenciais para a avaliação de sua execução. 


\subsubsection{A definição dos órgãos executores do PDFS}

A falta de metas para os programas influencia negativamente na definição dos órgãos executores do plano. Os órgãos executores do plano são os órgãos público ou privados que direta ou indiretamente serão responsáveis pelas metas estabelecidas para cada programa. Se não há metas estabelecidas, não há como definir quais serão os órgãos a serem envolvidos, nem o grau de participação de cada um deles na execução do plano

Segundo Carvalho (1978), a definição dos órgãos executores é uma medida que permite a implantação do processo de planejamento na sociedade, através de um complexo sistêmico de instituições. Isto significa "que as fases do processo de planejamento (...) devem ser materializadas em instituições respondendo por estas funções" (Carvalho, 1978, p86).

Há a menção destes órgãos no PDFS: as Prefeituras, organizações da sociedade civil, entidades ligadas à área florestal e à comunidade científica. Mas não há uma descrição detalhada para cada programa em cada setor, de quais as prefeituras, as organizações da sociedade civil, etc., que são citados como executores da proposta, nem o grau de participação de cada um no PDFS. Se os planejadores tivessem claras as metas para cada programa por setor, seria mais palpável a definição dos organismos a serem envolvidos e sua participação na consecução dessas metas.

\subsubsection{Os recursos financeiros e sua implicações}

Outro ponto essencial a constar de um plano são os recursos financeiros envolvidos. É importante ressaltar que os recursos financeiros necessários para a implantação e execução dos objetivos e metas globais do PDFS são da ordem de 4,5 bilhões de dólares distribuídos ao longo de 25 anos. Uma vez que nestes valores a participação por tipo de florestas (exóticas para reflorestamento e nativas para proteção e conservação) é praticamente meio a meio, cada setor, 
privado e público, deverá obter 2,25 bilhões de dólares no prazo citado, ou seja, em média, 90 milhões de dólares por ano.

\subsection{A orçamentação e o orçamento-programa}

A execução de um plano tem uma relação direta com a sua orçamentação e com uma previsão orçamentária, sem as quais as proposições desejadas não se complementarão. É algo como "tomar decisões, sem ter sobre o que decidir" (Carvalho, 1978, p.172). Assim, deve constar nos planos um orçamento-programa, "orçamento público que especifica não somente os custos dos diversos programas (...), desdobrados setorialmente, por funções, segundo as categorias de despesas de custeio e capital, mas também as metas físicas anuais que devem ser atingidas mediante a aplicação dos recursos orçamentários" (Ferreira, 1975, p.1011).

\subsection{Os recursos financeiros e a política econômica}

Apesar de não ser explicitado um orçamento-programa, o Estado é colocado como uma das principais fontes de financiamento previstas para o PDFS. Isso fica claro quando, ao se analisar as fontes de financiamento previstas para a execução do Plano, lê-se: "Para os programas ligados à área de conservação, a participação majoritária ficará a cargo do Estado, (...)" (Fundação, 1993, p.29).

Assim, não é de se esperar que uma soma da ordem de mais de $\mathbf{9 0}$ milhões de dólares/ano a ser utilizada para a execução do PDFS venha da própria previsão orçamentária do governo do Estado, que vem nesta última década, efetuando cortes de gastos com o objetivo de reduzir o déficit orçamentário e equilibrar as suas contas. A política de corte de gastos governamentais consolida-se no início dos anos 90, portanto antes do 
lançamento do PDFS, e é parte do processo de redução do tamanho do Estado, descentralização e privatização aqui já comentados.

Cabe indagar aqui sobre as conseqüências de se conceber um Plano da amplitude do PDFS sem levar em consideração as limitações representadas pelas tendências de reforma do Estado de orientação neoliberal adotadas no país.

Contrariando a política econômica neoliberal adotada pelo Governo Federal, seria possível obter ou movimentar os recursos anuais do erário estadual da ordem de 90 milhões de dólares durante 25 anos? Em duas publicações de avaliação administrativa, ambas da própria instituição formuladora do Plano, a Fundação Florestal, é possível extrair elementos que indicam que não. Em 1994, numa avaliação da gestão 91/94 da Fundação Florestal, é apresentada uma tabela na qual é possível perceber que o Tesouro Estadual foi diminuindo os repasses de recursos à Fundação. Esta tabela é reproduzida abaixo (tabela 1$)$ :

Tabela 1: Total da receita da Fundação Florestal no período 1990-julho1994, em US\$1.000

\begin{tabular}{|c|c|c|c|c|c|c|c|}
\hline Receita/ano & $\mathbf{1 9 9 0}$ & $\mathbf{1 9 9 1}$ & $\mathbf{1 9 9 2}$ & $\mathbf{1 9 9 3}$ & $\mathbf{1 9 9 4}$ & Total & $\%$ \\
\hline Própria & $5.952,90$ & $5.720,69$ & $5.828,13$ & $5.532,66$ & $2.477,93$ & $25.512,31$ & 34,2 \\
\hline Tesouro & $19.066,40$ & $9.368,54$ & $6.867,65$ & $8.083,54$ & $5.584,83$ & $48.970,96$ & 65,8 \\
\hline Total & $25.019,30$ & $15.089,23$ & $12.695,78$ & $13.616,20$ & $8.062,76$ & $74.483,27$ & 100,0 \\
\hline
\end{tabular}

Fonte: Fundação (1994)

Na mesma publicação, pode-se ler: "Percebe-se ter havido um decréscimo contínuo nas despesas de investimento (...) tendência que tem se verificado em praticamente todas as atividades de governo."(Fundação, 1994, p.18). 
Numa outra publicação, um relatório interno da Diretoria de Assistência Técnica, de março de 1996, em sua página 3, pode-se ler: “Com a mudança da gestão da Fundação Florestal (...) além das dificuldades político/institucionais geradas pelo descompasso do período de mandato da sua Diretoria com o Governo Estadual, aliado aos expressivos cortes financeiros $e$ de pessoal, teve-se um ano pouco produtivo, ..." (Fundação, 1996, p.3, grifado por R.B.M.). No mesmo relatório ainda se lê: "A partir de dezembro/95, foi definido como prioritário o estabelecimento de diretrizes para um modelo operacional que considere: (...) a redução de Recursos Humanos e a situação financeira crítica; (...)." (Fundação, 1996, p.4).

Ainda pode-se argumentar que no Plano há a indicação de obtenção de recursos que não viriam diretamente dos cofres da Fundação: "recursos provenientes de renegociações da dívida externa brasileira também não estão descartados, sendo porém objeto de procedimentos mais complexos" (Fundação, 1993, p.29). Também é citada a possibilidade de obtenção de verbas via organizações internacionais não-governamentais, e mesmo de organismos internacionais oficiais.

Neste contexto, os planejadores cometeram dois erros. O primeiro é a elaboração do Plano em dissonância com a direção da política econômica e orçamentária que vinha sendo adotada pelo governo federal e seus rebatimentos sobre as unidades da federação. Carvalho (1976) assinala: “é necessário acentuar que os procedimentos de planejamento estão diretamente relacionados com o regime político do país em consideração" (Carvalho, 1978, p.88). Em tais procedimentos incluem-se os mecanismos de obtenção de recursos para a execução do plano.

Assim, considerando apenas os dados extraídos de publicações de avaliação administrativa da própria Fundação, é possível perceber que o Governo Estadual vem implementando políticas que seguem a tendência de 
redução do papel do Estado e corte nos investimentos públicos ditada pelo governo federal, com claro prejuízo para a área ambiental que não é vista como essencial pelo mesmo (Ferreira \& Siviero, 1996). A própria redução de recursos de investimentos para a Fundação Florestal consubstanciam o alinhamento com esta política. Seguindo essa tendência de cortes de investimentos ambientais, como propor, de forma minimamente realista, que recursos da renegociação da dívida externa também entrem neste contexto ${ }^{27}$ ? O PDFS foi elaborado sem levar em consideração a política econômica do país, tendo implicações diretas na obtenção de recursos necessários para a sua implantação e execução dentro da meta prevista.

O segundo erro cometido pelos planejadores é conseqüência do primeiro: o tempo previsto ou estipulado para a consecução das metas em dissonância com os recursos financeiros disponíveis ou mobilizáveis. Antes de se consolidar as metas de um plano, é preciso realizar um estudo de coerência, ou seja, o plano deve ser avaliado várias vezes, para que se possa determinar a coerência entre os objetivos, as metas, a infra-estrutura, os recursos humanos e financeiros, para se determinar disparidades ou inconsistências no conjunto do plano, principalmente entre metas e recursos disponíveis (Carvalho, 1978). É em função deste estudo que as metas devem ser redimensionadas.

Segundo Carvalho (1978), "um esforço de síntese deve ser desenvolvido (...) refere-se à consolidação dos recursos estimados para custear os programas para cada setor ao nível de plano. (...). E, não somente a determinação dos gastos estimados como as fontes previstas para a captação de recursos" (Carvalho, 1978, p.102). Se a proposta é efetivamente implementar o PDFS para que ele alcance as metas determinadas, não podemos entender "fontes previstas" como

${ }^{27}$ À página 29 do PDFS lê-se: "Recursos provenientes da renegociação da dívida externa brasileira também não estão descartados, sendo porém objeto de procedimento mais complexos. Ao longo do período do Plano, podem vir a ser outra fonte importante de financiamento" (Fundação, 1993, p.29, grifado por R.B.M). 
possibilidades de obtenção de recursos. Devem existir fontes concretas, proposições e comprometimento de ordem financeira que assegurem a sua consecução.

Isso implica na previsão das fontes de financiamento e a ordem de recursos a serem obtidos de cada uma delas, indicando para quais programas serão direcionados. Se os recursos vierem da previsão orçamentária do governo, deve haver um planejamento de investimentos, ou seja, um programa orçamentário em sua administração que garanta o aporte de verbas necessárias para a execução do Plano.

Os planejadores devem sempre ter em mente a exeqüibilidade do plano. Um planejamento é elaborado porque se objetiva uma intervenção que se realizará no futuro, sendo uma formulação racional e consciente de um conjunto de decisões para orientar uma ação futura. É isso que o distingue de um mero ato impulsivo e de improvisação, por mais sábias que estas possam ser (Amato, 1966).

\subsection{Instrumentos econômicos e a geração de recursos financeiros}

Isso posto, a questão que agora se coloca é: em um governo que adota uma política de cortes de investimentos na área ambiental, é possível desenvolver mecanismos ou instrumentos que assegurem ou gerem recursos financeiros para a execução das metas de um plano nessa área?

A resposta encontra-se no próprio PDFS, que se propõe a ser um planejamento indicativo, visando influenciar a adoção e a execução de determinadas decisões por parte da iniciativa privada. Assim, ele exerce um controle indireto, que se dá pelo emprego de instrumentos políticos e econômicos de maneira programada, sobre o setor privado florestal, possibilitando ao Governo do Estado de São Paulo alterar as diretrizes da política florestal atual. 
Políticas ambientais que objetivem a indução de condutas adequadas, por parte de indivíduos ou da iniciativa privada, podem se basear em restrições legais de comando e controle ou, alternativamente, em instrumentos econômicos (Bacha, 1998). O mecanismo de comando e controle consiste na criação de normas e padrões de conduta ou qualidade ambiental e do estabelecimento, através da força de lei, de contravenções e punições nos casos de não cumprimento das normas e padrões prescritos. Segundo São Paulo (1998), a adoção de mecanismos de comando e controle vem sendo insuficiente para promover o controle da qualidade ambiental, sendo necessária a adoção concomitante de instrumentos econômicos.

Instrumentos econômicos ambientais são benefícios e/ou incentivos de ordem econômica-financeira criados com o objetivo de incentivar a adoção de comportamentos que promovam a melhoria da qualidade do ambiente (São Paulo, 1998). Dentre estes instrumentos destacam-se os tributos, que assumem a forma de impostos e taxas, e os subsídios, que assumem a forma de subvenções, empréstimos subsidiados e incentivos fiscais ${ }^{28}$. Tais instrumentos, quando aplicados em associação a um planejamento de caráter indicativo, podem influenciar a iniciativa privada a adotar decisões congruentes com os objetivos estabelecidos em uma determinada política ambiental.

Um bom exemplo da aplicação destes instrumentos econômicos como parte de um planejamento indicativo é o Programa de Reposição Florestal do Governo do Estado de São Paulo. Este Programa, que objetiva renovar recursos

${ }^{28}$ Tributos: toda prestação pecuniária compulsória. em moeda ou cujo valor nela se possa exprimir, que não constitua sanção de ato ilícito, instituida em lei e cobrada mediante atividade administrativa plenamente vinculada; impostos: modalidade de tributo que tem por hipótese de incidência um fato qualquer, não consistente numa atuação estatal; taxas: são tributos que têm por hipótese de incidência uma atuação estatal, decorrente de serviço público ou de poder de polícia diretamente referida ao contribuinte (São Paulo, 1998, p.15). Subsidios: formas de assistência financeira; subvenções: assistências financeiras não reembolsáveis; empréstimos subsidiados: taxas de juros abaixo das taxas do mercado; incentivos fiscais: depreciação acelerada ou outras formas de isenção ou abatimento de impostos (São Paulo, 1998, p.11). 
naturais como madeira, xaxim, plantas medicinais e ornamentais (São Paulo, s/d), é um dos componentes do PDFS voltado para o estímulo de reflorestamento com espécies exóticas para fins de produção e abastecimento do mercado de madeira, e possui uma organização que o diferencia de outros Estados da União.

A reposição de matéria-prima florestal utilizada pela iniciativa privada está prevista no artigo 20 da Lei Federal $n^{\circ} 4771 / 65$, o Código Florestal Brasileiro, onde o consumidor de matéria-prima florestal deverá "manter (...) um serviço organizado, que assegure o plantio de novas áreas, em terras próprias ou pertencentes a terceiros, cuja produção, sob exploração racional, seja equivalente ao consumido para o seu abastecimento" (Brasil, s/d, p.7). A reposição florestal, portanto, é obrigatória em todo o território nacional. $\mathrm{O}$ próprio Código prescreve, ainda, em seu artigo 14, que tanto o poder público federal quanto o estadual poderão prescrever outras normas em função de peculiaridades locais.

Em função disso, o IBAMA ${ }^{29}$ estabeleceu que os consumidores de matéria-prima florestal devem repor, em número de árvores, o volume equivalente a quantidade de matéria prima utilizada em suas atividades. Isso pode ser feito mediante:

1. recolhimento de uma taxa, ao extinto IBDF³, hoje IBAMA, a Taxa de Reposição Florestal Obrigatória (TRFO).

2. projetos de reflorestamento ou plano de exploração e manejo florestal;

3. participação em projetos de terceiros, implantados para essa finalidade por empresas especializadas $\mathrm{e}$;

4. vinculação de projetos incentivados à obrigação de reposição.

\footnotetext{
${ }^{29}$ Instituto Brasileiro do Meio Ambiente e dos Recursos Naturais Renováveis.

${ }^{30}$ Instituto Brasileiro e Desenvolvimento Florestal.
} 
Dessa forma, o consumidor de matéria-prima florestal pôde optar por fazer a reposição utilizando os seus próprios meios, ou repassar esta atribuição ao poder público ${ }^{31}$ que aplicaria tais recursos em projetos de florestamento e reflorestamento, bem como a implantação e a recuperação de florestas de essências nativas (Bacha, 1998).

O ano de 1986 foi um marco para o Programa de Reposição Florestal no Estado de São Paulo, pois iniciou-se um processo que o diferenciou dos outros Estados: a criação de Associações de Reposição Florestal, entidades civis sem fins lucrativos, formadas por consumidores de madeira, que se encarregariam do recolhimento da Taxa de Reposição Florestal Obrigatória e do plantio das árvores correspondentes ao montante recolhido. Essa inovação ocorreu em decorrência de questionamento, por parte dos próprios consumidores de madeira, da utilização efetiva dos recursos gerados pela TRFO para o plantio de novas áreas com florestas. As Associações reivindicavam seu reconhecimento e credenciamento, pelos órgãos públicos federal e estadual (respectivamente, IBAMA e DEPRN), como instituições que gerenciariam tal recurso de maneira eficiente para cumprir o objetivo a que se propunha a TRFO.

Após uma longa batalha judicial, IBAMA e DEPRN reconheceram a formação das Associações de Reposição Florestal e publicaram a Resolução Conjunta SMA/SP-4 de 3 de dezembro de 1993, que estabeleceu as normas para o cumprimento da reposição florestal no Estado de São Paulo, dando a opção para os consumidores de produtos florestais paulistas de cumprir a reposição florestal obrigatória por meio de reflorestamento próprio, ou de recolhimento à associação civil sem fins lucrativos (as Associações de Reposição Florestal) que se encarregaria do plantio.

${ }^{31}$ Isso não se aplica aos grandes consumidores que são obrigados a manter plantios próprios. Ver São Paulo (s/d) e Brasil (s/d). 
Aos órgãos públicos, no caso o IBAMA e o DEPRN, cabe o papel de órgãos de fiscalização dos trabalhos das Associações e de coordenação das atividades da reposição florestal no Estado.

A maior parte dos recursos financeiros das Associações de Reposição Florestal destina-se à produção de florestamentos e reflorestamentos homogêneos de Eucaliptus sp. e Pinus sp., com vistas ao abastecimento do mercado de madeira. A outra parte é aplicada para a recuperação de áreas degradadas e de matas ciliares (São Paulo, s/d).

O trabalho das Associações caracteriza-se como uma atividade de fomento florestal, pois com os recursos arrecadados são produzidas mudas de essências florestais que são doadas à pequenos e médios produtores interessados, com a devida assistência técnica até a idade de corte desse plantio. Por meio deste trabalho de fomento florestal, as Associações de Reposição Florestal vêm fomentando, desde a sua criação, o plantio efetivo de 6 milhões de árvores por ano.

$O$ trabalho de fomento florestal funciona de forma adequada nesta escala porque induz os proprietários rurais a terem florestamentos $\mathrm{e}$ reflorestamentos em suas propriedades. Fornecendo gratuitamente assistência técnica e mudas, o fomento reduz os custos de produção da madeira. $O$ desembolso financeiro feito pelo produtor ocorre apenas nas operações de plantio e manutenção das mudas. Independentemente da finalidade que será dada à madeira, após o corte das árvores, a implantação dos reflorestamentos e florestamentos torna-se economicamente mais atraente.

Por meio da regulamentação das Associaçōes de Reposição Florestal, organizações da sociedade civil, os órgãos ambientais federal e estadual criaram um mecanismo eficiente de reposição da madeira consumida no Estado e permitiram, com bases legais e sustentação jurídica, a participação da sociedade civil na implementação da política florestal paulista. 
Panificadoras, pizzarias, olarias, churrascarias, cerâmicas, serrarias e quaisquer outros estabelecimentos que transformem madeira em sua atividade são, por força de lei, obrigadas a pagar uma taxa referente ao seu consumo para que as Associações coordenem novos reflorestamentos. Quem financia o Programa de Reposição Florestal são aqueles que diretamente se beneficiam dele, os consumidores de madeira, que passam a ter a garantia de novos plantios que irão fornecer a madeira a ser utilizada em suas atividades, garantia essa representada pelo incentivo que o Programa oferece ao plantio por parte de proprietários rurais e pela regulação do mercado daí decorrente.

Mais do que o benefício que representa para os consumidores de madeira, a importância da Reposição Florestal e da Taxa de Reposição Florestal Obrigatória reside em sua implicação ambiental: a contribuição dada à proteção das matas nativas através da garantia de fornecimento de madeira através de reflorestamentos, evitando assim o corte de árvores nativas para abastecimento do mercado de madeira.

O Programa de Reposição Florestal é, portanto, um instrumento econômico que ultrapassa as limitações impostas pelas ações restritivas de uso dos recursos naturais renováveis, complementando-as ao atuar de forma preventiva na proteção das florestas nativas.

A utilização da Taxa de Reposição Florestal Obrigatória como instrumento econômico de financiamento e de incentivo, possibilitou ao Governo do Estado de São Paulo induzir o reflorestamento de florestas homogêneas, pela captação de recursos fora do âmbito meramente orçamentário. É um exemplo eficiente da adoção de uma política de ação de fomento, dentro de um planejamento de caráter indicativo.

E no caso das florestas de proteção e conservação? É possível criar mecanismos semelhantes de financiamento e incentivo à recuperação das áreas de preservação permanente como prevê o PDFS? Na realidade, os programas 
do Plano partem do mesmo princípio que tornaram o trabalho das Associações de Reposição Florestal bem sucedido: fomentar o plantio de mudas de espécies florestais nativas com fins de preservação e conservação como estímulo à recuperação das áreas de preservação permanente do Estado.

Como o fomento é uma subvenção, ou seja, uma assistência financeira não reembolsável, ele caracteriza-se como um instrumento econômico que visa influenciar a adoção de determinadas decisões (implantação de áreas de preservação permanente) por parte do setor privado (proprietários rurais). É portanto um instrumental de planejamento de caráter indicativo, que visa auxiliar o Governo do Estado de São Paulo na implementação das diretrizes de sua atual política florestal e do PDFS.

Há uma diferença significativa entre os instrumentais políticoeconômicos utilizados no Programa de Reposição Florestal e aqueles utilizados nos Programas de Conservação e Preservação do PDFS. Apesar de ambos trabalharem com subvenções (fomento de mudas), a captação de recursos para os Programas de Conservação e Preservação não foi prevista fora do âmbito orçamentário do Estado. Também não foram criados ou utilizados instrumentos de financiamento como a Taxa de Reposição Florestal, mas atribuiu-se ao Estado o ônus de grande parte dos investimentos necessários para a execução de tais Programas. Como o Estado pode gerar e assegurar recursos financeiros para os Programas em que deve investir?

Em 1991, dois anos antes do lançamento do PDFS, o Estado do Paraná apresentava uma resposta à esta pergunta, pelo estabelecimento do ICMS 32 Ecológico $^{33}$. O ICMS Ecológico é o nome dado ao montante de recursos

${ }^{32}$ ICMS é uma sigla que significa: imposto sobre operações relativas à circulação de mercadorias e sobre prestação de serviços de transporte interestadual e intermunicipal e de comunicação. Do total arrecadado com este imposto, $25 \%$ pertencem aos municipios e, destes $25 \%$, 1/4 poderá ser creditado conforme dispuser lei estadual (São Paulo, 1998).

33 ICMS Ecológico: Lei Complementar Estadual n 59 de 01-10-1991, regulamentada pelo Decreto Estadual nº 974 de 09/12/1991 (Bacha, 1998; São Paulo. 1998). 
provenientes do ICMS arrecadado pelo Estado e devolvido aos municípios em função da existência de áreas, em seu território, com restrições de uso e ocupação do solo, por serem consideradas espaços territoriais especialmente protegidos pelo Estado - unidades de conservação ambiental (São Paulo, 1998).

A regulamentação do ICMS Ecológico só é possível porque $25 \%$ do produto de arrecadação do ICMS no Estado pertence ao município. A estes 25\% dá-se o nome de Fundo de Participação dos Municípios no ICMS, dos quais "três quartos, no mínimo, deverão ser creditados segundo o critério valor adicionado, e um quarto, conforme dispuser lei estadual." (São Paulo, 1998, p.37, grifado no original).

No caso paranaense, os municípios rateiam pelo ICMS Ecológico, segundo critérios técnicos, 5\% do Fundo de Participação dos Municípios no ICMS total arrecadado no Estado. Destes 5\%, metade é direcionada para os municípios que têm espaços territoriais especialmente protegidos ${ }^{34}$ pelo Estado. A outra metade é direcionada para os municípios que protegem os mananciais públicos. Assim, "a distribuição é feita de acordo com a área total preservada e com a qualidade de água, fazendo com que os municípios incluídos nos critérios percam ou tenham esse direito diminuído, se reduzirem suas áreas preservadas ou piorarem a qualidade da água" (São Paulo, 1998, p.53).

O ICMS Ecológico é um instrumento econômico de compensação financeira dada aos municípios por preservarem parcelas de seu território em detrimento de atividades econômicas. É uma concessão de subsídios para que se conservem os recursos florestais e aquáticos (Bacha, 1998).

${ }^{34}$ Foram considerados espaços territoriais especialmente protegidos aqueles correspondentes às seguintes unidades de conservação: "estações ecológicas, reservas biológicas; parques estaduais, reservas florestais, florestas nacionais, florestas municipais, áreas de relevante interesse ecológico, áreas de proteção ambiental, os refúgios de vida silvestre, os monumentos naturais, as áreas especiais e locais de interesse turístico, as reservas particulares do patrimônio nacional, as reservas indígenas e os hortos florestais" (Bacha, 1998, p. 168). 
Só no ano de 1994, foram repassados como ICMS Ecológico US\$ 24,6 milhões a 151 municípios paranaenses. Uma vez que o governo estadual não disciplina regras de uso do repasse adicional do ICMS, cabe aos municípios decidir como alocar tais valores. Seriam recursos valiosos a serem aplicados em programas de proteção e conservação ou projetos de recuperação de áreas de preservação permanente que influenciam diretamente a qualidade da água ao propiciarem a proteção dos mananciais de abastecimento que, por sua vez, tornam o município apto a receber uma parcela maior de recursos no rateio do ICMS Ecológico. É um caráter indutor presente na Lei do ICMS Ecológico paranaense, pois "quaisquer melhorias nas unidades de conservação ou na qualidade da água são captadas por fatores que determinam a parcela que cada município tem no repasse do ICMS ecológico" (Bacha, 1998, p.169).

Em São Paulo, o ICMS Ecológico foi instituído em 1993, pela Lei Estadual $n^{\circ} 8.510$ de 29 de dezembro de 1993. Ela prevê o repasse de apenas 0,5\% dos 25\% dos recursos do Fundo de Participação dos Municípios no ICMS aos municípios com unidades de conservação (Bacha, 1998; São Paulo, 1998), mas não inclui áreas de proteção aos mananciais. Mesmo sendo uma baixa proporção $(0,5 \%)$ se comparado a alíquota paranaense $(5 \%)$, foram transferidos a título de espaços territoriais especialmente protegidos no exercício de 1996, a importância de R\$33.082.106 (São Paulo, 1998).

Apesar deste considerável montante, o ICMS Ecológico no Estado de São Paulo não apresenta um caráter indutor, pois a melhoria da qualidade ambiental não é considerada como fator de distribuição destinado aos municípios. Assim, se o poder municipal direcionar os recursos do ICMS Ecológico para melhorias nas unidades de conservação ou na qualidade da água, estas não serão captadas por fatores que determinam a parcela que cada município tem no repasse do ICMS Ecológico. O município, portanto, pode direcionar estes recursos para outros setores que não o ambiental. 
Do ponto de vista ambiental, "a forma mais adequada de repasse do ICMS Ecológico aos municípios é aquele que induz a melhoria da qualidade ambiental, fazendo com que os mesmos tenham efetivo interesse na manutenção e na melhoria dessa qualidade" (São Paulo, 1998, p.41).

Por não incluir repasse de verbas para áreas de preservação de mananciais, o ICMS Ecológico paulista não auxilia na recuperação, conservação ou proteção de áreas de preservação permanente, como objetiva o PDFS. Mas mostra que é possível comprometer recursos financeiros que possam ser destinados à execução do Plano e dessa forma assegurar um dos elementos básicos para a sua consecução.

Há ainda outros instrumentos econômicos que atualmente estão sendo utilizados no Estado e que poderiam assegurar recursos financeiros, de maneira indireta, necessários à implementação do PDFS. Um deles é a "Compensação para espaços especialmente protegidos", benefício regulamentado pela Lei $\mathbf{n}^{\circ}$ 9.146/95 de 09 de março de 1995, instituindo mecanismos de compensação financeira aos municípios que têm em seus territórios, espaços especialmente protegidos criados pelo Estado ${ }^{35}$ (São Paulo, 1998). A concessão do benefício aos municípios está condicionada à situação das áreas protegidas e a critérios definidos pela lei, dentre os quais: recomposição florestal de nascentes e matas ciliares; combate à erosão; manutenção da biodiversidade dos ecossistemas; criação, fiscalização, defesa, recuperação, regularização fundiária e preservação de unidades de conservação e de sua fauna e flora; financiamento de projetos ambientais relacionados à efetivação destes critérios. Todos eles diretamente relacionados com os Programas de Conservação definidos no PDFS.

${ }^{35}$ Os espaços especialmente protegidos são as Unidades de Conservação (UC's). São elas: as Estações Ecológicas, Reservas Biológicas, Zonas de Vida Silvestre em Áreas de Preservação Permanente, Reservas Florestais, Áreas de Proteção Ambiental, Áreas Naturalmente Tombadas e os Parques Estaduais. 
Pode-se citar, ainda, o Imposto por desmatamento, Lei $n^{\circ} 4.771$ e Lei $n^{\circ}$ $7.803 / 89$, com o propósito de financiamento de projetos de reflorestamento público e atividades do serviço florestal do Estado.

Se há dificuldades quanto a um comprometimento orçamentário por parte do Governo devido à adoção de políticas que seguem a tendência de redução do papel do Estado e corte nos investimentos públicos na área ambiental, há a possibilidade da utilização de instrumentos econômicos como forma de geração de receitas direcionadas para a conservação florestal.

Pode-se citar o Programa de Recuperação de Matas Ciliares (PRMS) do Estado de Minas Gerais como exemplo. Os recursos para tal Programa provêm de fontes diversas, dentre as quais, taxas cobradas pelo Estado "dos agentes que utilizam, comercializam ou consomem produtos florestais" (Mueller, 1998, p.196).

Se na época da elaboração do Plano não existiam tais mecanismos ou, em virtude de sua existência ainda embrionária, não se podendo contar com eles como fontes financiadoras do Plano, atualmente eles são uma realidade. Bastaria haver uma organização administrativa, uma articulação entre o poder estadual e o municipal, que estimulasse os detentores destas novas fontes de recursos, os municípios, a que respondessem com eficiência aos estímulos do PDFS, direcionando estas verbas para a Conservação florestal e ambiental.

\subsection{Instrumentos econômicos e incentivo ao plantio}

A aplicação de instrumentos econômicos resolve o problema do poder público no sentido de angariar recursos necessários para subsidiar a preservação dos recursos naturais nativos sob a forma de unidades de conservação ou de matas protetoras dos recursos hídricos, como resposta às políticas de corte nos investimentos na área ambiental. 
Tanto o PDFS quanto outros programas estaduais de recuperação de matas protetoras de recursos hídricos, como os de Minas Gerais e Bahia ${ }^{36}$, canalizam os recursos para subvenções. Ou seja, utiliza-se um instrumento econômico visando incentivar o plantio por parte dos proprietários rurais, na forma de materiais e serviços (basicamente a assistência técnica gratuita e a doação de mudas).

Entretanto, os resultados alcançados permitem constatar que tal mecanismo não tem sido suficiente para incentivar proprietários rurais a aderir a tais programas. Isso ocorre tanto para o Programa de Recuperação de Matas Ciliares (PRMC) em Minas Gerais, quanto para o Programa de Recomposição Florestal de Matas Ciliares (PRFMC) na Bahia (Mueller, 1998).

A resposta remete novamente à discussão de objetivos comuns entre aqueles que planejam e aqueles que implementarão o Plano ou Programa. Os planejadores destes tipos de programas estão pressupondo que todos os outros atores sociais envolvidos, no caso os proprietários rurais, concordarão em recuperar as suas áreas de preservação permanente e reserva legal. Mas, se tais objetivos não forem de encontro às demandas do público a que se destina, não serão valorizados e sofrerão resistência.

Os planejadores do PDFS partiram do princípio que a sua leitura da situação florestal do Estado e as medidas concebidas para solucionar tais problemas são compartilhadas por todos os proprietários rurais paulistas. Daí concluíram que as subvenções, na forma de fomento, acelerariam o processo de recuperação das áreas de preservação permanente. Os produtores que não compartilham destas leituras, da necessidade de recuperar as áreas de preservação permanente e de reserva legal de suas propriedades, impõem resistência a este tipo de ação, o que compromete os objetivos e metas do PDFS, ou de qualquer outro plano.

\footnotetext{
${ }^{36}$ ver Mueller (1998).
} 
Esta resistência pode ser resumida em duas causas. A primeira resistência refere-se à obrigatoriedade legal de recomposição de áreas de preservação permanente e reserva legal ${ }^{37}$ por proprietários rurais, que questionam o porquê de reduzir a área produtiva para ser plantada com árvores que não poderão ser cortadas (no caso das matas ciliares), nem exploradas pelo corte raso (no caso da reserva legal). Tais questionamentos se fundamentam nas perdas econômicas da manutenção de áreas de preservação permanente e reserva legal ${ }^{38}$, tendo em vista o caráter restritivo do uso da terra que esta figura jurídica impõe (Bacha, 1998).

A força desta resistência pode ser medida pela pressão da "bancada ruralista" do Congresso Nacional sobre o Poder Executivo, que editou uma Medida Provisória, a MP n 1.736-31 assinada em 14 de dezembro de 1998, que libera o proprietário rural de reflorestar as suas reservas legais. Esta Medida Provisória ainda está em vigor.

Há ainda uma segunda causa da resistência por parte de proprietários em recuperar as áreas de preservação permanente. Se o produtor utiliza uma determinada área para a produção, recompô-las com espécies florestais nativas significa ter a sua renda reduzida. Ele não mais poderá utilizar esta área para a produção agrícola nem florestal, por não ser permitida a sua utilização econômica ${ }^{39}$. Seu patrimônio também será reduzido, pois haverá uma queda no valor da propriedade, por compreender uma área "não-produtiva" (Mueller, 1998).

${ }^{37}$ As Reservas Legais estão previstas no Código Florestal (Lei ${ }^{\circ} 4.771 / 65$ ) e devem ocupar de $20 \%$ a $80 \%$ da cobertura vegetal florestal na propriedade rural de acordo com o tamanho do imóvel, podendo ser exploradas economicamente, mas sem que haja o corte raso.

${ }^{38}$ Uma análise da viabilidade econômica da adoção de programas de recuperação e preservação de áreas ciliares, para uma microbacia, pode ser vista em Toledo (1997).

${ }^{39}$ Excetuando casos específicos, como por exemplo, o manejo de Euterpe edulis para a produção de palmito, desde que com autorização dos órgãos públicos responsáveis. 
Além da perda de patrimônio e da redução de sua renda, ele terá que arcar com parte dos custos da recuperação da área, ainda que receba mudas e assistência técnica gratuitas. A subvenção oferecida pelo Estado, portanto, não é o suficiente para incentivar o proprietário rural a recuperar as suas áreas de preservação permanente frente a todos estes fatores.

Segundo Mueller (1998), estes são problemas enfrentados pelos técnicos do PRMC mineiro e no PRFMC baiano. Em São Paulo, não é diferente. Prova disso é que oito meses após a aprovação da Lei Estadual $\mathrm{n}^{\circ} 9.989^{40}$, que obriga o proprietário rural a recuperar as suas áreas de preservação permanente, nenhum projeto de recomposição foi apresentado ao Departamento Estadual de Proteção de Recursos Naturais, dentro do prazo de 180 dias exigido pela Lei ${ }^{41}$.

Quais as soluções que poderiam incentivar plantio em áreas de preservação permanente pelo proprietário rural? Se pensarmos em instrumentos econômicos, existem propostas no sentido de transformar tais áreas em geradoras de renda. Por exemplo, Mueller (1998) cita o plantio de árvores que propiciassem a atividade extrativista sob regime especial de manejo; ou o plantio de árvores, como o Eucaliptus sp, como espécies do grupo sucessional das pioneiras ${ }^{42}$, que poderiam ser posteriormente extraídas sem o prejuízo da floresta nativa em formação. Tais idéias esbarram, atualmente, nas restrições do Código Florestal que não permite a utilização econômica destas áreas, excetuando casos específicos e sob condições muito rigorosas; e na falta de consenso por parte da comunidade científica e dos técnicos do setor ambiental paulista de que estas soluções resolveriam o problema.

${ }^{40}$ O Estado de São Paulo foi o primeiro a obrigar o proprietário rural a recuperar as suas áreas de preservação permanente.

${ }^{41}$ Ver "Paulistas descumprem..." (s/d).

${ }^{42}$ Espécies do grupo sucessional das pioneiras, são espécies florestais de rápido crescimento que propiciam condições ambientais de desenvolvimento para as espécies do grupo sucessional das não pioneiras, que formarão o corpo da mata. 
Outra forma de utilizar instrumentos econômicos para incentivar a implantação das áreas de preservação permanente seria aumentar as subvenções ao proprietário rural, além da doação das mudas e assistência técnica, fornecendo também recursos financeiros para diminuir os custos que lhe cabem para a implantação de tais áreas, além da perda do fluxo de renda e da desvalorização patrimonial, principalmente em pequenas propriedades ${ }^{43}$.

No entanto, não se deve adotar os instrumentos econômicos para o incentivo à recuperação de áreas de preservação permanente como a única solução possível para a questão. Há situações em que ela não se aplica e outras em que será desnecessária. Por exemplo, situações em que os proprietários rurais, entendendo a necessidade e a importância das áreas de preservação permanente, aderem aos programas de doação de mudas e assistência técnica voluntariamente, assumindo os custos financeiros de sua implantação $0^{44}$.

Portanto, tais programas devem tentar identificar se há, e quais são, os fatores (problemas, dificuldades e aspirações) que determinam a resistência por parte dos produtores rurais em implantar as áreas de preservação permanente, possibilitando desenvolver estratégias que apontem para possíveis soluções. Para facilitar o desenvolvimento de tais estratégias, pode-se agrupar os fatores seguindo a classificação idealizada por Galjart (1973).

Segundo este autor, sempre que se deseja introduzir alguma alteração ou inovação no sistema de produção do produtor rural, e ela não se concretiza, o fator por trás desta resistência pode ser creditado à ignorância, à impotência e ao desinteresse.

A ignorância se refere à falta de saber, à ausência de conhecimento por parte do produtor para adotar uma inovação ou mudança tecnológica no seu sistema de produção. A incapacidade diz respeito a não poder, por razões

\footnotetext{
${ }^{43} \mathrm{Um}$ aprofundamento desta questão pode ser encontrado em Toledo (1997).

${ }^{44} \mathrm{O}$ caso da fazenda Crisciumal ilustra esta situação. Ver Queiroz (1993).
} 
financeiras ou outras razões, adotar uma inovação ou mudança, mesmo tendo o conhecimento de como fazê-lo. E o desinteresse refere-se ao fato do produtor saber o que deve ser feito para adotar uma inovação ou mudança tecnológica, objetivamente poder fazê-lo, mas não o querer. Há um conjunto de valores e atitudes que, se mantidos, detém o produtor de implantar as inovações ou mudanças tecnológicas (Galjart, 1973).

Apesar desta classificação ter sido idealizada para se identificar fatores sociológicos que afetam o desenvolvimento agrícola, ela facilmente pode ser utilizada para identificar quais os fatores sociológicos que afetam a incorporação de árvores numa propriedade rural. Se os produtores não implantam árvores em suas propriedades é porque existem fatores que os impedem, relacionados à ignorância ou à impotência ou ao desinteresse em implantar áreas de preservação permanente na propriedade rural.

Mais do que simplesmente classificar, a organização dos fatores nestas três categorias facilita a visualização dos problemas que impedem a incorporação do componente arbóreo por parte do produtor rural. Há um mapeamento destes problemas por grupo, problemas que necessitam de soluções específicas e estratégias diferenciadas.

Ela permite constatar quais os casos em que os instrumentos financeiros não serão suficientes para incentivar o proprietário rural a aderir aos Programas de Conservação e recuperação de áreas de preservação permanente.

O uso dos instrumentos econômicos, como as subvenções, é uma estratégia a ser utilizada para casos em que o proprietário não pode, por razões financeiras ou estruturais, implantar sua área de preservação permanente, mesmo tendo o conhecimento e o desejo de fazê-lo. Mas não se aplica a produtores que tem o conhecimento, a capacidade mas não querem implantar as áreas de preservação permanente devido a uma leitura diferente da situação que lhe é apresentada. 
Portanto, tentar identificar os fatores que determinam a resistência por parte dos produtores rurais em implantar as áreas de preservação permanente e agrupá-los segundo a classificação de Galjart (1973), é um importante instrumento para o desenvolvimento de estratégias adequadas, que apontem para soluções racionais do problema da recuperação de áreas de preservação permanente. Mais do que isso, possibilita ao planejador trabalhar com os diversos atores sociais com as mais variadas leituras e intenções de ações.

Todos estes programas que objetivam a recuperação de áreas ciliares e de preservação permanente, incluso o PDFS, não levam em consideração a possibilidade do proprietário rural ter uma leitura diferente da situação da baixa cobertura florestal, a partir da sua aspiração, condição e experiência de vida. Cada produtor avalia a situação que lhe é apresentada de modo particular e atua segundo sua própria interpretação da realidade. Se o conflito existente nestas opiniões diversas for trabalhado, poderá ser utilizado na construção de objetivos que orientem o planejamento. Caso contrário, o proprietário oporá resistência, e as metas do Plano não serão cumpridas.

Esta é a importância de se apresentar os objetivos definidos pelos planejadores antes de serem transformados em metas, para apreciação e discussão, principalmente às populações, aos grupos ou indivíduos que, direta ou indiretamente, estão ou estarão envolvidos no processo de planejamento, ou sofrerão os efeitos da intervenção nele programada.

A partir dos argumentos expostos, pode-se perceber que houve imprecisões no cumprimento das etapas do processo de planejamento, concernentes a elaboração do PDFS. A primeira foi adotar uma concepção tradicional de planejamento. Apesar de ser um dos tipos de planejamento difundido e utilizado, ele priva os executores de participarem das definições dos objetivos do Plano. Se os executores não concordam com o resultado que se pretende alcançar pelo desenvolvimento de uma atividade, tal objetivo não 
encontrará respaldo e sua implementação poderá tornar-se inviável. Isso posto, quantificar os objetivos a serem alcançados num prazo definido, ou seja, estabelecer metas a serem cumpridas, perde seu efeito.

Esta é uma crítica que não se refere apenas ao PDFS, mas a forma de elaboração de um planejamento tradicional ou normativo. Sempre que um plano não discutir seus objetivos e metas com os executores da intervenção, não estará considerando as diferentes leituras de uma situação que se apresenta. Isto implica numa não adesão daqueles que não concordam com as proposições das soluções. Portanto, deve-se adotar um planejamento que trabalhe com as diferentes leituras dos diferentes atores sociais, para envolvê-los na proposta e execução da intervenção a ser feita.

Quanto às metas especificadas no PDFS, além do equívoco acima mencionado que compromete a sua consecução, o Plano também estabeleceu um intervalo de tempo muito longo para atingir seus objetivos. A tendência seria um Plano de curto à médio prazo para providenciar reformas na estrutura administrativa do Estado adequando-a para cumprir os seus objetivos. Além disso, em 25 anos, não há garantias de apoio político ao Plano pelas mudanças de governo que irão ocorrer. Todos estes fatores, não observados, influenciam a execução das metas previstas.

Quanto aos recursos financeiros, é possível concluir que há várias imprecisões no tocante à sua obtenção e administração. Não é apresentada uma previsão orçamentária e muito menos um orçamento-programa para os Programas definidos. Considera-se que o Estado assuma um ônus, quando este vem adotando uma política de corte de investimentos, negligenciando-se o uso de outras opções de geração de renda, como os instrumentos econômicos. Sem dúvida este foi um ponto, dentre todos os demais apresentados, de maior imprecisão no PDFS. 
Por fim, foram estabelecidos quatro Programas e, em apenas dois, são apresentadas as metas a serem atingidas sem que haja uma explicitação dos organismos executores do PDFS. Tampouco, estudos de coerência entre as metas e os recursos disponíveis, porque a definição de ambos foi negligenciada nos Programas.

O Plano de Desenvolvimento Florestal Sustentável, portanto, é um planejamento tradicional, de caráter indicativo, que seguiu etapas básicas necessárias para a elaboração de um plano. A sua elaboração vai até a definição dos programas, mas não avança em seu detalhamento, o que compromete as próximas etapas do processo de planejamento posteriores à sua elaboração, como veremos a seguir.

\subsection{As etapas do processo de planejamento posteriores à elaboração do PDFS}

Se ficar apenas no papel, o plano será um documento político que abrange um conjunto de decisões tomadas pelo governo, que procura orientar as ações públicas e privadas na prática do desenvolvimento (Carvalho, 1978), mas não se constituirá como uma intervenção que busca alterar a realidade de um determinado setor.

Após o estudo de coerência, o plano deve ser executado, colocado em prática, para que sua viabilidade seja testada e para que o processo de planejamento possa ter continuidade. É sempre importante ter claro que os planos são um meio e não um fim em si mesmo. Eles são um documento, ou seja, um conjunto de medidas expressas, mas "que conta infinitamente menos que o processo de planejamento" (Waterson, citado por Carvalho, 1978, p.42).

A definição dos órgãos executores é uma medida que permite a implantação do processo de planejamento na sociedade, por meio de instituições com atribuições previamente definidas. Num processo de planejamento, o plano daí resultante é materializado em instituições públicas ou 
privadas que direta ou indiretamente respondam pelas funções da intervenção que se deseja executar e pela contribuição aos projetos a serem implementados. No caso do PDFS, o que ocorre é uma falta de institucionalização do Plano, fruto das imprecisões que ocorreram em sua elaboração, mais especificamente, não há uma definição dos órgãos executores.

O que o Plano apresenta é uma proposta de organização em que se prevê um órgão coordenador composto pela Fundação Florestal e as instituições participantes $^{45}$ da execução do Plano determinadas de acordo com funções previamente estabelecidas. Por meio da indicação de seus representantes, tais instituições, fariam uma "intermediação entre a execução e o controle, através de informes e reuniões periódicas" (Fundação, 1993, p.43). No Anexo 1, pode-se ver o organograma que reflete esta organização proposta no PDFS, enquanto uma proposta de institucionalização do Plano.

A imprecisão que se apresenta é fruto do lançamento do PDFS Ter-se realizado antes de se articular o contato entre a Fundação Florestal e as instituições participantes. Tal articulação deveria ter sido feita quando da formulação do Plano e não no decorrer de sua execução. Mais do que isso, para definir as suas metas gerais e a dos programas, o Plano precisaria já ter determinado quem iria executá-las e de que forma o fariam.

Segundo a proposta de articulação e participação dos órgãos executores presente no PDFS, eventuais equívocos na determinação dos objetivos e metas dos Programas seriam corrigidos na fase de execução, pois tais articulação e participação resultariam em uma realimentação de informações para correção dos rumos do Plano (ver Anexo 1).

Em um relatório da diretoria de assistência técnica da Fundação Florestal fica claro que a implementação da organização proposta para o envolvimento dos agentes locais não foi feita a contento. Isto pode ser detectado 
em duas passagens: "Inúmeras dificuldades de formulação e compreensão conceituais foram detectados ao longo da implementação do PDFS, dada a falta de instrumentos de decodificação do Plano em ações específicas, acabando por dificultar os mecanismos de operacionalização das atividades regionais" (Fundação, 1996, p.7); e também: "Bem aceito pelos meios acadêmicos, científicos e institucionais pela sua consistência teórica, o PDFS carecia de projeto executivo de implantação, apresentando pouca eficácia, (...) (Fundação, 1996, p.2, grifado por R.B.M.).

Os problemas referentes à operacionalização do Plano causam distorções em pelo menos dois aspectos que são muito importantes para a sua implementação de maneira racional e planejada.

A primeira distorção relaciona-se com a própria organização administrativa do Estado, que deveria ter sido estruturada de forma a levar adiante os processos necessários para a concretização de suas proposições, pelo menos no âmbito dos órgãos públicos estaduais que compõem a Secretaria de Meio Ambiente.

Entretanto, a própria Fundação Florestal detecta problemas na coordenação entre os órgãos da Secretaria no sentido de centralizar esforços e ações para a consecução do Plano. $O$ relatório da Diretoria de Assistência Técnica chama a atenção para o problema e propõe que: “A partir de dezembro/95, foi definido como prioritário o estabelecimento de diretrizes para um modelo operacional que considere: (...) a possibilidade de maior integração dos órgãos do SISEMA46" (Fundação, 1996, p.4). Mais à frente, pode ler-se: "Para a implementação das açōes regionais, a integração se torna desejável quando se propõe que toda a rede de estruturas regionais do SISEMA se constituam em

\footnotetext{
${ }^{45}$ Não há no PDFS a menção ou explicitação de quais seriam estas instituições participantes.

${ }^{46}$ Sistema Estadual de Meio Ambiente.
} 
importante instrumento para a efetiva implantação do PDFS" (Fundação, 1996, p.9, grifado no original).

$O$ resultado da falta de articulação entre as estruturas regionais dos órgãos da Secretaria do Meio Ambiente pode ser observada, por exemplo, no fato da Fundação Florestal fomentar a produção de 30.000 mudas no município de Bauru, através de contrato com um parceiro local, quando o Instituto Florestal, também órgão da Secretaria do Meio Ambiente, já tinha um viveiro com infra-estrutura instalada no mesmo município (Fundação, 1996).

A falta de estabelecimento de relações entre órgãos da mesma Secretaria para a implantação do PDFS não implica, necessariamente, que o Plano não será executado. Entretanto, dado que o PDFS é um documento de intervenção elaborado pelo Estado, seria de se esperar que os órgãos públicos do setor florestal e de meio ambiente trabalhassem em conjunto para uma execução coordenada e racional daquilo que o governo entende ser a política do setor, para o qual a sua organização administrativa deveria estar voltada.

Há ainda uma segunda distorção na operacionalização do PDFS, a ausência de um projeto executivo que coordene as ações entre a Fundação Florestal e os órgãos executores locais, através da criação de uma estrutura regional de coordenação das ações.

Sem um projeto executivo de implantação, ou seja, um detalhamento de como serão feitas as articulações com os órgãos executores, um plano não tem como estabelecer um grau de detalhamento de sua intervenção no âmbito de projetos. O PDFS, ao carecer de projeto executivo, acaba definindo apenas linhas globais de ação que dificilmente conseguirão ser executadas e avaliadas. E este fato não parece ser incomum, pois Carvalho (1978) observava que é comum haver planos sem a implantação do processo de planejamento, ou seja, uma tendência à especulação intelectual ou de incitação à ação, antes mesmo de projetos precisos para realizar. Ou seja, um plano sem projetos apresenta-se em 
um nível de excessiva generalidade, não devendo ser considerado como instrumento operacional a não ser nos níveis de decisão mais elevados (Carvalho, 1978).

O estabelecimento de uma estrutura regional de coordenação de ações é objeto de um projeto executivo de implantação. Na ausência deste, o PDFS ficou desprovido de coordenação regional, com a Fundação Florestal atuando no varejo sem critérios que direcionassem as ações empreendidas para atingir os objetivos do Plano. Cabe ressaltar que o Plano previa a criação de núcleos regionais que não foram efetivados.

Mesmo sem um projeto executivo de implantação e sem a criação dos núcleos regionais, a Fundação Florestal adotou a estratégia de investir recursos humanos e financeiros no Programa de produção e distribuição de sementes e mudas florestais. O objetivo desse Programa era tornar viável a produção e a distribuição de sementes e mudas de essências nativas e exóticas para o atendimento das metas globais previstas no PDFS. Uma das principais ações adotadas foi o estabelecimento de parcerias para a produção de mudas. Os parceiros recebiam da Fundação assistência técnica e insumos (sementes, sacos plásticos, substratos, tubetes, mesas para tubetes e sombrite) e como contrapartida destinava parte de sua produção à Fundação ${ }^{47}$. Com este esquema, 121 contratos de parceria foram firmados (Fundação, 1996), sendo que em 1996 apenas seis estavam em vigor.

Numa avaliação destes contratos de parceria pela Fundação Florestal, conclui-se pela necessidade de estabelecer critérios para a definição destas parcerias, evidenciando-se uma carência de diagnóstico de demandas, seleção e

${ }^{47}$ Os planejadores do PDFS partiram do princípio que a sua leitura da situação florestal do Estado e que as medidas concebidas para solucionar tais problemas são compartilhadas por todos os proprietários rurais paulistas. $\mathrm{O}$ que era considerado um empecilho ao cumprimento das metas do PDFS não eram leituras diferentes por parte dos proprietários rurais, mas apenas a falta de mudas para o cumprimento de suas metas. 
hierarquização de parceiros. Esta carência é fruto das distorções de operacionalização a que nos referimos anteriormente e se materializa na definição de parcerias sem a realização de um diagnóstico das demandas por mudas de determinadas regiões, ou seja, a escolha das parcerias foi realizada sem o apoio de critérios que a estruturassem.

Em resumo, a falta de uma operacionalização planejada resulta na ausência de uma estrutura capaz de captar as demandas regionais e estabelecer contratos de parcerias que possam atender as necessidades de recomposição florestal das diferentes regiões do Estado. Isso resultou, em alguns casos, na aplicação de recursos para produção de mudas em regiões onde não havia demanda por elas e, em outros casos, na ausência de apoio em regiões em que se apresenta uma demanda por mudas, conforme ilustraremos abaixo.

A própria Fundação reconhece a aplicação de recursos em locais onde não há demanda, como se depreende da afirmação: "foram fomentados três viveiros, totalizando $400 \mathrm{mil}$ mudas, sem justificativa técnica (demanda, capacidade produtiva dos viveiros, etc)" (Fundação, 1996, p.3).

Os problemas que advêm da ausência de coordenação regional podem ser ilustrados pela análise de caso do município de Porto Feliz.

Localizada nos limites da Bacia do Sorocaba/Médio Tietê, Porto Feliz apresenta uma microbacia, a do ribeirão Avecuia, quase que totalmente contida nos limites do município. Atualmente, é a principal fonte de abastecimento de água da cidade, uma vez que não há possibilidades de abastecimento por águas subterrâneas. Um patrimônio municipal, que necessita ter sua qualidade e quantidade preservada, para não ser preciso bombear água do Rio Tietê, cuja qualidade da água já está totalmente comprometida.

Observando os dados da cobertura florestal nativa nas matas ciliares para todos os cursos da rede de drenagem do Avecuia, " (...) deveria haver uma 
área total de $25,37 \mathrm{~km}^{2}$ com mata ciliar, na bacia do Rio Avecuia. A área de mata ciliar existente, entretanto, é de 8,5 km²." (Ezaki, 1996, p.37).

Frente à importância das matas ciliares, este valor mostra-se insuficiente para garantir uma qualidade e quantidade de água suficiente para o abastecimento público da cidade de Porto Feliz. As matas ciliares apresentam importante função para a melhoria da quantidade e da qualidade das águas fluviais. Apesar de isoladamente não resolverem o problema, sua implantação é uma medida, dentre outras necessárias, que contribuirá de maneira significativa para futuramente garantir o abastecimento do município. A importância de reflorestar o restante da área de mata ciliar da microbacia do ribeirão do Avecuia é, portanto, um fato que não pode ser desconsiderado.

Os Programas de Conservação e de Proteção do PDFS, estão "voltados, sobretudo, para as matas nativas" (Fundação, 1993, p.31), tendo como um de seus objetivos prioritários o replantio de matas ciliares nas bacias e microbacias. Um alinhamento dos objetivos do PDFS com as necessidades dos municípios através de uma estrutura de coordenação regional poderia ter criado, no caso de Porto Feliz, condições de um trabalho conjunto no âmbito das instituições públicas para a recuperação das matas ciliares do Avecuia.

Não tendo havido este alinhamento, a Prefeitura, por meio do S.A.A.E. ${ }^{48}$, deu início a medidas de ação no sentido de captar recursos para a implantação de um viveiro para a produção de mudas de espécies florestais nativas que seriam destinadas, em sua maioria, para a recuperação das matas ciliares da microbacia do Ribeirão Avecuia. Ao final do ano de 1998, o S.A.A.E. obteve recursos que possibilitaram o início da implantação de um viveiro no ano de 1999.

\section{Feliz.}

${ }^{48}$ Sistema Autônomo de Água e Esgoto, autarquia municipal vinculada à Prefeitura de Porto 
Uma curiosidade que vale ser ressaltada é que, ainda que não tendo traçado metas, o início da intervenção municipal para recuperação da microbacia do Ribeirão Avecuia em Porto Feliz/SP vem seguindo os mesmos procedimentos realizados para a elaboração do PDFS. Pretende atingir seus objetivos sem envolver os executores da proposta - os proprietários rurais - em sua configuração, supondo que a simples distribuição de mudas é o suficiente para recompor as áreas de mata ciliar do Avecuia, o que poderá levar a intervenção municipal ao fracasso, pelos motivos que aqui já foram expostos.

Tanto o superintendente como a engenheira agrônoma responsável pelo setor de meio ambiente do S.A.A.E., respectivamente idealizador e responsável pela operacionalização da proposta de recuperar as matas ciliares do Avecuia, não sabiam o que vinha a ser o PDFS e nem a que se propunha.

Poderia argumentar-se, em defesa da organização proposta no PDFS para a institucionalização do Plano (ver Anexo 1), que embora não se previsse que o órgão coordenador fizesse este diagnóstico da demanda regional, haveriam instâncias regionais que o fariam. Há de se concordar com isso. Não seria função do órgão coordenador do PDFS, ele próprio, diagnosticar as demandas por região. Mas se a organização proposta tivesse sido operacionalizada como previsto, a demanda de Porto Feliz poderia ter sido identificada. Assim, o núcleo regional, caso tivesse sido implantado, identificaria órgãos executores do Plano que teriam condições de formular projetos locais que fossem de encontro com os objetivos e metas do Plano. $\mathrm{O}$ reflorestamento ciliar da microbacia do Avecuia seria um destes casos, no qual o S.A.A.E. seria um órgão executor, propondo um projeto de execução do PDFS.

O estabelecimento de maneira insatisfatória da organização da implantação do PDFS também remete a uma imperfeição de uma etapa muito importante em um processo de planejamento: a avaliação do plano. Como Carvalho (1978) observa: 
“O fato de ter elaborado um plano de desenvolvimento e as decisões nele contidas passarem à prática não significa que esse plano esteja sendo executado. Somente o processo sistemático de controle e a periódica avaliação é que informarão ao centro de decisões se realmente o previsto está sendo executado. $O$ equívoco que se verifica é: formulação científica do plano e sua implantação de forma empírica" (Carvalho, 1978, p. 112).

No Plano foi proposta uma avaliação a ser realizada pelo sistema estruturado para implantação do Plano. Quem avalia o que está sendo executado sãos os órgãos executores, as instituições que implementam os projetos, as menores unidades do processo de planejamento. Uma vez que houve falhas na operacionalização do Plano, como aqui foi exposto, é de se esperar que haja falha em sua avaliação.

Por exemplo, a Fundação conseguiu estabelecer uma avaliação no tocante à produção de mudas com 48 de seus parceiros. Por meio desta avaliação, constatou-se que de 3.821 .000 mudas contratadas, foram produzidas 441.274 mudas e, destas, 232.601 foram distribuídas. Ou seja, dos 48 parceiros contratados, distribuiu-se apenas $6 \%$ do total a ser produzido. Esta avaliação permitiu à Fundação perceber que deveriam ser estabelecidos critérios para a seleção de parceiros em função, inclusive, da demanda por mudas nas regiões. Os dados obtidos permitiriam também deduzir que não se conseguiria atingir as metas do Plano.

Mas, como não houve uma operacionalização da implantação do Plano, não havia um sistema de realimentação efetivo. A avaliação deveria ser um procedimento padrão, com regras discutidas e pré-determinadas com os órgãos executores que, numa cadeia reversa, enviariam as informações ao órgão 
coordenador. Dessa forma, o órgão coordenador teria uma visão conjunta da execução do Plano em todo o Estado. A presença dos órgãos executores como fornecedores de informações para a avaliação é prevista no Plano: "Individualmente ou em conjunto, as instituições (...) fará uma intermediação entre a execução e o controle, através de informes e reuniões periódicas" (Fundação, 1993, p.43).

Como isso é um reflexo de uma operacionalização planejada, e não foi executada a contento, as avaliações feitas com os 48 parceiros foram realizadas pelo órgão coordenador, a Fundação Florestal. Como havia 121 viveiros contratados e a Fundação Florestal não apresentava uma estrutura para proceder à avaliação precisa, o questionário de avaliação foi realizado sem a presença do técnico no momento da resposta, em função da diminuição do quadro de pessoal da instituição, havendo, inclusive, questionários não respondidos.

Como, por exemplo, avaliar se as mudas que foram distribuídas foram plantadas? Quantas destas mudas morreram? Ainda que as 3.821 .000 mudas contratadas para a produção tivessem sido produzidas e distribuídas, a pergunta permanece: quantas efetivamente teriam transformado-se em árvores? Como avaliar se a melhor estratégia é apenas fomentar viveiros se não se sabe quantas mudas realmente vingaram? Não seria melhor fazer convênios com as Casas de Agricultura, que apresentam um trabalho de extensão rural?

O fato de a Fundação ter procedido à avaliação sem a presença de um técnico no momento das respostas, em razão da diminuição do quadro de pessoal da instituição, demonstra a necessidade de se ter uma organização bem estruturada entre o órgão coordenador e os órgãos executores, sem a qual a realimentação de informações essenciais para a reformulação do Plano não ocorrerá. E o que se conclui é uma falta de institucionalização do Plano, fruto 
das imprecisões que ocorreram na elaboração do PDFS, exatamente no tocante a uma estrutura da relação com os órgãos executores.

Um planejamento é mais do que elaborar um Plano e colocar em prática as decisões nele contidas. É um processo que caracteriza-se como um conjunto de etapas pelo qual irá se realizar uma determinada intervenção. Portanto, enquanto um processo, ele obedece a relações de interdependência que o identifica como um conjunto de partes relacionadas entre si. Um conjunto coerente, que deverá produzir resultados finais ou objetivos, que facilitem o aumento da eficácia da intervenção.

Apesar de indispensáveis para que haja um planejamento, um plano faz parte do processo e constitui um documento de referência, mas não é o planejamento em si. O plano é um documento orientador de um processo maior, sistematizado, que é o planejamento, que serve para comunicar certas informações e coordenar as ações para atingir as metas previstas. Para tanto, deve cumprir etapas básicas. Etapas nas quais o PDFS não cumpriu ou o fez com deficiência, conforme foi explicitado e discutido.

Ainda que incorrendo em imperfeições nas etapas concernentes à sua elaboração, para que sua viabilidade seja testada e para que o processo de planejamento possa ter continuidade, o Plano deve ser executado, colocado em prática, obedecendo etapas posteriores à sua elaboração. Se ficar apenas no papel, ele será apenas um documento político que abrange um conjunto de decisões tomadas pelo governo, que procura orientar as ações públicas e privadas na prática do desenvolvimento mas não se constituirá em uma intervenção que busca alterar a realidade de um determinado setor.

Num processo de planejamento, o plano daí resultante é materializado em instituições públicas ou privadas que direta ou indiretamente respondam pelas funções da intervenção que se deseja executar e pela contribuição aos 
projetos a serem implementados. No caso do PDFS, o que ocorre é uma falta de institucionalização do Plano, fruto das imprecisões que ocorreram em sua elaboração, mais especificamente, não havendo uma definição dos órgãos executores, sem a qual a realimentação de informações essenciais para a reformulação do Plano não ocorrerá.

E nesse sentido, a própria organização administrativa responsável pela implantação do plano deverá estar dimensionada para levar adiante os processos necessários para a concretização de suas proposições.

Dado que o PDFS é um documento de intervenção elaborado pelo Estado, seria de se esperar que os órgãos públicos estaduais trabalhassem em conjunto para uma execução coordenada e racional daquilo que o governo entende ser a política de um setor, para o qual a sua organização administrativa deveria estar voltada. E a falta de estabelecimento de relações, não só entre os órgãos da Secretaria de Meio Ambiente como foi discutido, mas entre as diferentes Secretarias de Estado, é muito clara.

Se um dos objetivos do Plano é utilizar a educação ambiental para “conscientizar a população para o seu papel de beneficiária final do processo de conservação (...)" (Fundação, 1993, p.10), qual o envolvimento da Secretaria Estadual de Educação com o PDFS? Houve um trabalho em conjunto para o desenvolvimento de atividades de educação ambiental em todas as escolas de cada município do Estado? Se para a consecução dos objetivos do Plano, atividades de extensão seriam necessárias, qual o envolvimento da Secretaria de Agricultura e Abastecimento com o PDFS? Houve um trabalho em conjunto para o desenvolvimento de atividades de extensão florestal com as Casas de Agricultura de cada município do Estado? Não há menção no PDFS de um trabalho coordenado entre tais Secretarias, ou qualquer outra Secretaria que pudesse contribuir na consecução dos objetivos ou nas atividades do Plano. 
A visão de planejamento do governo, expressa com a elaboração do PDFS e sua (não)execução coordenada e racional, para o qual a sua organização administrativa deveria estar voltada, mostra uma visão imperfeita de planejamento. Uma ausência de concepção de planejamento enquanto um processo de intervenção de todo um governo e seus órgãos, para com um Plano que deveria ser assumido como sendo a política de um setor, e que precisa ser executado e avaliado, permitindo reformular o diagnóstico inicial, a política de desenvolvimento e o próprio plano, conduzindo, em alguns casos, à elaboração de um novo plano.

É principalmente por estes motivos, e também por todos os outros apontados nesta dissertação, que pode-se afirmar que o PDFS foi apenas um Plano com um fim em si mesmo, um resultado isolado, que não fez parte de um processo mais amplo de intervenção, de um planejamento para o setor florestal paulista. $\mathrm{O}$ seu lançamento, portanto, nada mais foi, do que a sua própria morte anunciada. 


\section{CONCLUSÕES}

1. O PDFS caracteriza-se como um Planejamento Tradicional, configurado por um único ator social, o Estado, e não incorpora a visão dos outros atores sociais que deveriam ser envolvidos na execução do planejamento, os proprietários rurais. Portanto, o Plano não encontra respaldo entre os executores e sua implementação sofre resistências, tendendo, até, a tornar-se inviável. Esta resistência por parte dos executores do Plano foi identificada pela Fundação Florestal, sendo apresentada como um fator responsável pela pouca eficácia do PDFS.

2. As metas do PDFS foram estabelecidas sem levar em consideração que os atores sociais envolvidos na sua execução, os proprietários rurais, têm diferentes leituras sobre a situação da cobertura florestal e sobre a necessidade de recuperar as áreas de preservação permanente e reserva legal. Ou seja, sem considerar uma possível resistência pelos implemetadores do Plano, o que compromete a consecução de suas metas.

3. Com relação ao espaço de tempo previsto para a consecução de tais metas, o PDFS é um plano de longo prazo, quando a tendência seria a elaboração de um plano de curto ou de médio prazo, para: (i) ser possível providenciar possíveis reformas na estrutura administrativa visando sua adequação para a implantação 
de procedimentos de decisão e controle mais aprimorados e; (ii) garantir a viabilidade política para a implantação do Plano.

4. O PDFS estabelece suas metas em dissonância com os recursos financeiros disponíveis ou mobilizáveis, nos quais o Plano:

- não conta com um orçamento programa e uma orçamentação, sem as quais as proposições desejadas não se complementarão;

- prevê a utilização de recursos financeiros da própria previsão orçamentária do governo, sem levar em consideração as limitações representadas pelas tendências de reforma do Estado de orientação neoliberal adotadas no país;

- não se utiliza de instrumentos econômicos para a geração e/ou comprometimento de recursos financeiros para a implantação do Plano.

5. Os Programas apresentados no PDFS não foram detalhados. $O$ não estabelecimento de metas influencia negativamente na definição dos órgãos executores do Plano e no grau de participação de cada um deles na sua implementação.

6. O uso de instrumentos econômicos utilizados no Plano, no caso, as subvenções, não tem sido suficiente para incentivar proprietários rurais a aderir a tais programas. Há situações em que tais incentivos não se aplicam, e outras em que serão desnecessários, em função da leitura dos proprietários rurais sobre a necessidade de recuperar as áreas de preservação permanente e reserva legal de suas propriedades.

7. Há a ausência, no PDFS, de estratégias múltiplas para captar e trabalhar as leituras dos diferentes proprietários sobre a recuperação das áreas de preservação permanente e reserva legal, que propiciariam ao Plano uma maior 
flexibilidade de ação. Para facilitar o desenvolvimento de tais estratégias, é aconselhável que se identifique os fatores que determinam a resistência por parte dos produtores rurais em implantar as áreas de preservação permanente e reserva legal, agrupando-os segundo a classificação de Galjart (1973). Tal classificação possibilita ao planejador trabalhar com os diversos atores sociais com as mais variadas leituras e intenções de ações.

8. O PDFS foi lançado antes de se articular o contato entre a Fundação Florestal e as instituições participantes. Tal articulação deveria ter sido feita quando da formulação do Plano e não no decorrer de sua execução, para definir as suas metas gerais e a dos programas, já determinando quem iria executá-las e de que forma o fariam.

9. Não há, no Plano, um projeto executivo que coordene as ações entre a Fundação Florestal e os órgãos executores locais, por meio da criação de uma estrutura regional de coordenação das ações, não tendo como estabelecer um grau de detalhamento de sua intervenção no âmbito de projetos.

10. A falta de uma operacionalização planejada resultou na ausência de uma estrutura capaz de captar as demandas regionais e estabelecer contratos de parcerias que possam atender às necessidades de recomposição florestal das diferentes regiões do Estado, como ilustrado com o caso do município de Porto Feliz.

11. O Plano apresenta imperfeições na estruturação da organização administrativa do Estado de forma a levar adiante os processos necessários para a concretização de suas proposições, enquanto política para os setor florestal. A 
falta de estabelecimento de relações, não só entre os órgãos da Secretaria de Meio Ambiente, mas entre as diferentes Secretarias de Estado, é muito clara.

12. Por todos os itens acima enumerados, pode-se concluir que o PDFS foi apenas um Plano com um fim em si mesmo, um resultado isolado, que não fez parte de um processo mais amplo de intervenção, de um planejamento para o setor florestal paulista. 


\section{Articulação e participação dos agentes}

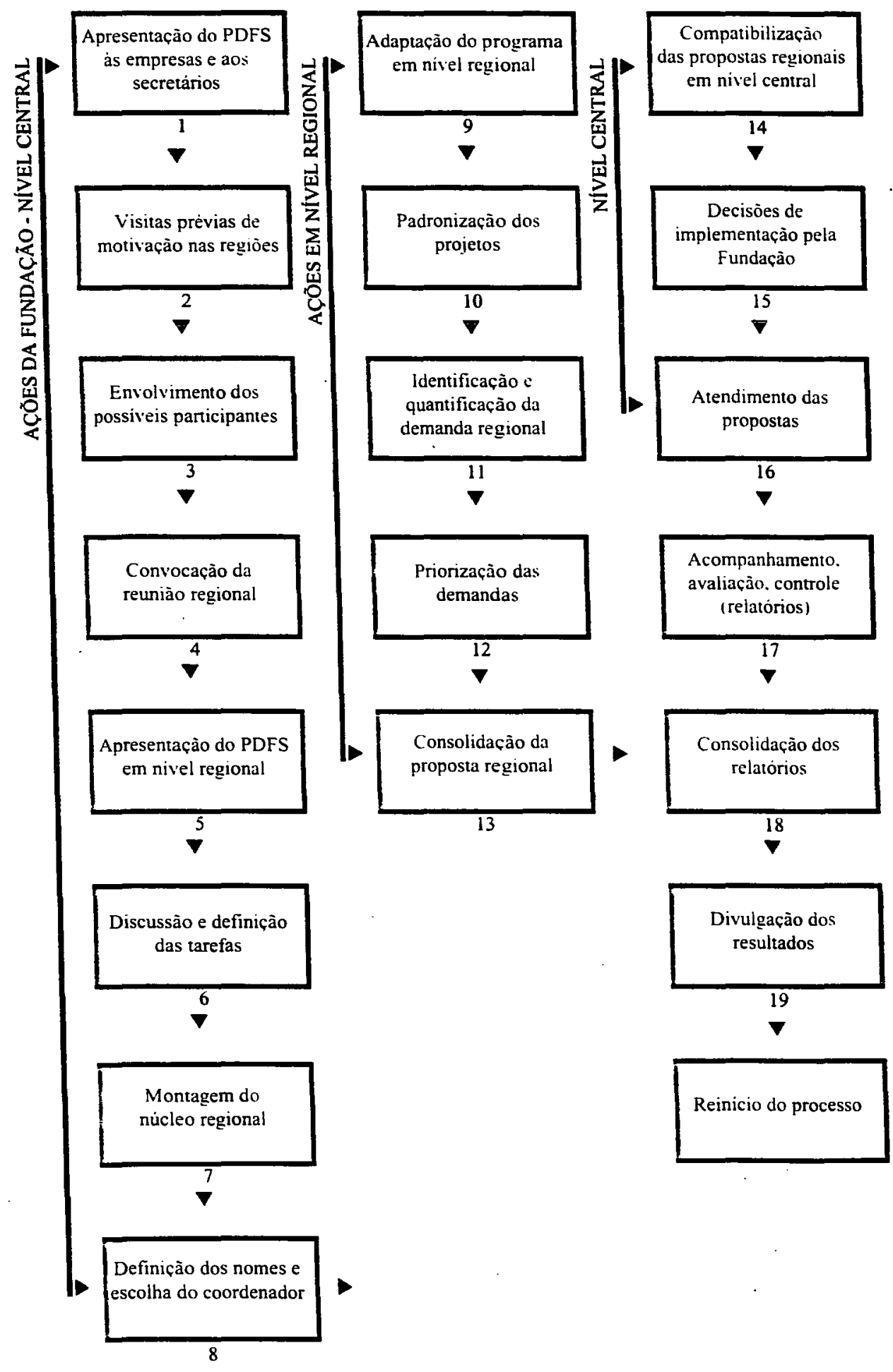




\section{REFERÊNCIAS BIBLIOGRÁFICAS}

ACIESP - ACADEMIA DE CIÊNCIAS DO ESTADO DE SÃO PAULO. Glossário de ecologia. 2 ed. São Paulo: Publicações ACIESP nº 103, 1997.

ACKOFF, R.L. Planejamento empresarial. 1 ed. Rio de Janeiro: Livros Técnicos e Científicos Editora S.A., 1981. 126p.

ALMEIDA, J.R. de (Coord.) Planejamento ambiental. Rio de Janeiro: Thex Editora Ltda, 1983. 154p.

AMATO, P.M. Planejamento. Rio de Janeiro: Fundação Getúlio Vargas, 1966 (Cadernos de administração pública ${ }^{\circ} 33$ ).

ARROYO, M. Planejamento: exercitando a democracia. São Paulo: s. ed., 1996. 12p. (Coleção Pedagógica Trilha).

BACHA, C.J.C. Gestão Florestal no Paraná. In: LOPEZ, L.V.; BASTOS FILHO, G.S.; BILLER, D.;BALE, M. (org.) Gestão Ambiental. Rio de Janeiro: Editora Fundação Getúlio Vargas, 1998. p. 155-182.

BASCUR, F. Las multiplas dimensiones del Bosque. Chile Forestal (177), out 1990, p14-15.

BERTONI, J. \& LOMBARDI NETO, F. Conservação do solo. São Paulo: Ícone Editora, 1990. 355 p. (em especial capítulo 9)

BOTLER, M. Planejamento estratégico e operacional. In: KLAUSMEYER, A.; RAMALHO, L. Introdução a metodologias participativas - um guia prático. Recife: Sactes/Ded - Abong, 1995. p. 59 - 76 
BRAGA, T.M. Políticas sociais no Brasil das duas últimas décadas. Apresentado como trabalho de avaliação final da disciplina Teoria e Desenvolvimento Econômico do programa de doutorado em economia aplicada do IE/UNICAMP, 1998/ 7P.

BRAGA, T.M. Desenvolvimento local endógeno e suas aplicações na formulação de políticas ambientais municipais. In: VIII Encontro Nacional da ANPUR, Porto Alegre, 1999. Anais eletrônicos. Porto Alegre, 1999.

BRASIL. Lei Federal $\mathrm{n}^{\circ} 4.771$ de 15 de setembro de 1965 (alterada pela Lei Federal $n^{\circ} 7.803$ de 18 de julho de 1989). In: Estado de São Paulo. Secretaria de Estado do Meio Ambiente. Coordenadoria de Proteção de Recursos Naturais. Departamento Estadual de Proteção de Recursos Naturais. Código Florestal. São Paulo, s/d. 12p.

CARVALHO, H. M. de. Introdução à teoria do planejamento. 2 ed. São Paulo: Editora Brasiliense, 1978. 176 p.

CASTANHO, E. P.de et alli. Proposta de política pública para o Estado de São Paulo - Plano Emergencial. Publicação do Instituto Florestal. São Paulo, 24:1-42. jun 1984

CESP. Cesp promove regeneração de matas nativas. Silvicultura. São Paulo, v15, n 55, p.32-35, mai-jun. 1994.

DRAIBE, S. América Latina: o sistema de proteção social na década das crises e das reformas. In: Cadernos NEPP, $n^{\circ}$ 30. Campinas: NEPP/UNICAMP. 1995

EFIMOV, A. \& ANCHISHKIN, A. A planificação econômica, seus fins e realização prática. Lisboa: Prelo Editora - S.A.R.L. ,1972. 205 p.

EZAKI, S. Proposta de gestão de Recursos Naturais da Bacia Hidrográfica do Rio Avecuia - Município de Porto Feliz (SP). São Paulo, 1996. 72p. Monografia (Graduação) - Faculdade de Filosofia, Letras e Ciências Humanas - Universidade de São Paulo.

FAO. Forestry and food security. Roma, 1989.128 p.

FERREIRA, A.B.H. Novo dicionário da língua portuguesa. 1e. Rio de Janeiro: Editora Nova Fronteira S.A., 1975. 1517p. 
FERREIRA, L. \& SIVIERO, S. Ambiente e Cidades em direção à uma nova agenda. São Paulo em Perspectiva, v.10, n.3, p.60-70, 1996.

FUNDAÇÃO FLORESTAL. Plano de Desenvolvimento Florestal Sustentável. São Paulo: A Fundação, 1993. 47 p.

FUNDAÇÃO FLORESTAL. Gestão 91/94. São Paulo: A Fundação, 1994. 48 p.

FUNDAÇÃO FLORESTAL. Estruturação da Gerência de Desenvolvimetno Florestal. São Paulo,1996. 20 p. (relatório interno)

GALJARD, B. Divisão cultural, modernização e subdesenvolvimento. In: SZMRECSÁNYI, T.; QUEDA ,O. , Vida Rural e Mudança Social. 3 ed. São Paulo, Companhia Editora Nacional, 1979. p. 57-65

HUERTAS, F. O Método PES: entrevista com Matus. São Paulo: FUNDAP, 1996. 139p.

INSTITUTO FLORESTAL. Inventário Florestal do Estado de São Paulo. São Paulo, IF, 1993. 199p.

IUCN. Estratégia Mundial para a Conservação: a conservação dos recursos vivos para um desenvolvimento sustentado. São Paulo: CESP, 1984, $1 \mathrm{v}$.

IUCN. Cuidando do Planeta Terra. Uma Estratégia para o Futuro da Vida. São Paulo: Editora CL-A Cultural, 1991. 246 p.

JARA, C. Planejamento do desenvolvimento municipal com participação de diferentes atores sociais. Debates, $n^{\circ} 11$, p. 9-40, 1996.

LAFER, B. M. O conceito de planejamento. In: LAFER, B. M., Planejamento no Brasil. São Paulo: Editora Perspectiva, 1970. p.9-28 (Coleção Debates, $\mathbf{n}^{\circ}$ 21)

LAFER, C. O planejamento no Brasil - observações sobre o plano de metas (1956-1961). In: LAFER, B. M., Planejamento no Brasil. São Paulo: Editora Perspectiva, 1970. p.9-28 (Coleção Debates, $n^{\circ} 21$ )

MUELLER, C.C. Gestão de Matas ciliares. IN: LOPEZ, IV.; BASTOS FILHO, G.S.; BILLER, D.;BALE, M. (org.) Gestão Ambiental. Rio de Janeiro: Editora Fundação Getúlio Vargas, 1998. p. 185-214. 
PAULISTAS DESCUMPREM LEI DE REFLORESTAMENTO. Folha de São Paulo, nov. 1998

QUEDA, O. \& SZMERCSÁNYI, T. O papel da educação escolar e da assistência técnica. In: SZMRECSÁNYI, T.; QUEDA ,O. , Vida Rural e Mudança Social. 2 ed. São Paulo, Companhia Editora Nacional, 1976. p. 216-233

QUEIROZ, L.R.S. Fazendeiro replanta mata ciliar e traz de volta as aves e animais. Estado de São Paulo. Suplemento Agrícola, São Paulo, 12 mai 1993.

RIQUE, M. Planejamento estratégico situacional - PES. Debates, $n^{\circ} 11$, p. 131$144,1996$.

SÃO PAULO (Estado). Secretaria de Estado do Meio Ambiente. Coordenadoria de Proteção de Recursos Naturais. Departamento Estadual de Proteção de Recursos Naturais Reposição Florestal. São Paulo, s/d. 3 p.

SÃO PAULO (Estado). Secretaria de Estado do Meio Ambiente Instrumentos econômicos e financeiros. São Paulo, 1998. 263 p.

SERRA FILHO, R. Levantamento da cobertura vegetal natural e do reflorestamento no Estado de São Paulo. Bol. Técnico do IF (11): 1-53, out 1975.

SILVA, P. L. B. Reforma do estado e política social no brasil: êxitos, problemas e desafios aos gestores sociais. CAMPINAS: NEPP/UNICAMP, 1998. MIMEO.

SZMERCSÁNYI, T. O planejamento da agroindústria canavieira no Brasil (1930-1975). São Paulo: Editora Hucitec-Unicamp, 1979. 539p. (em especial cap. 1)

TINBERGEN, J. Desenvolvimento planejado. Rio de Janeiro: Zahar Editores, 1975. 229p.

TOLEDO, P.E.N. Impacto ambiental e análise econômica de medidas mitigadoras: o caso da microbacia hidrográfica do córrego São Joaquim, Pirassununga (SP). Piracicaba, 1997. 142 p. Tese (Doutorado) - Escola Superior de Agricultura Luiz de Queiroz, Universidade de São Paulo. 
TROPPMAIR, H. A cobertura vegetal primitiva do estado de São Paulo baseada em estudos toponímicos, históricos e ecológicos. Ciência e Cultura , 26 (3): 240-43. 1974

VICTOR, M. A. M. A Devastação Florestal. São Paulo: Sociedade Brasileira de Silvicultura, $1975.48 \mathrm{p}$.

WALINSKY, L.J. Planejamento e execução do desenvolvimento econômico. Rio de Janeiro: Zahar Editores, 1965. 244 p. 